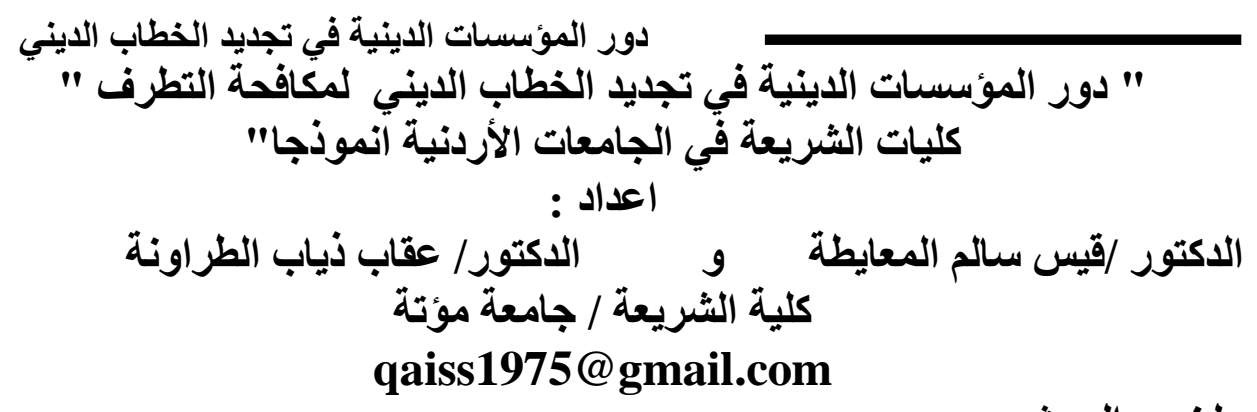

ملخص البحث فذا البحث محاولة لإثبات أن للمؤسسات الدينية ، لها دور كبير في تنشئة

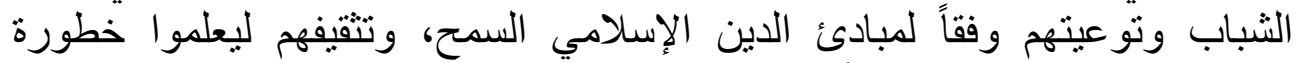

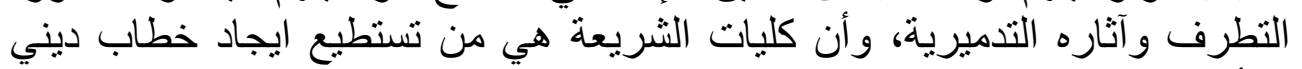

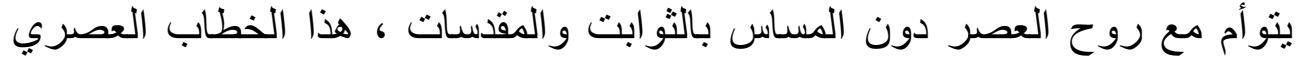

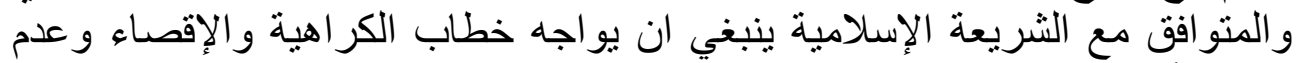

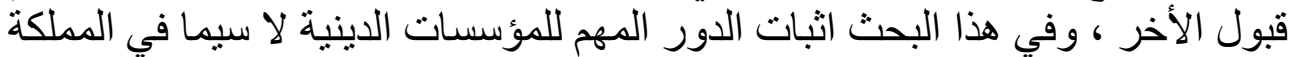

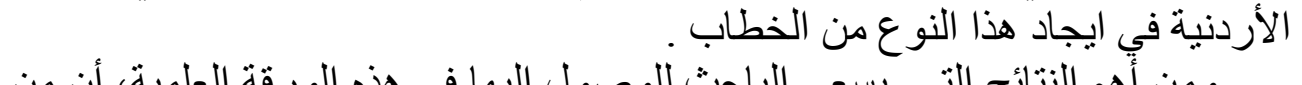

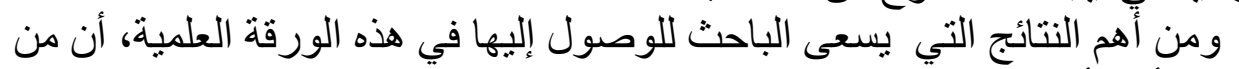

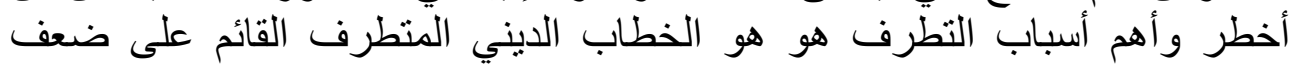

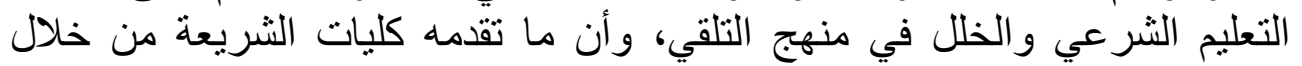
مختلف مساقاتها ما هو إلا ترسيخ لمبادئ الإسلام وقيمه النبيلة القائمة على التئ الوسطية

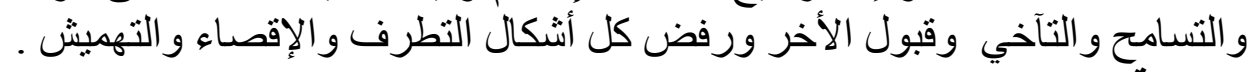
المقدمة الله رب العالمين والصلاة والسلام عى اشرف الخلق وسيد المرسلين وعلى الهي وصحبه (جمعين وبعد : لا شك أن للمؤسسات الدينية و التربوية دور كبير في بناء الإنسان حضاريا

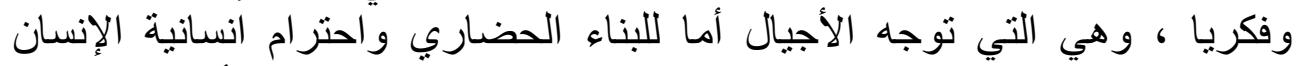

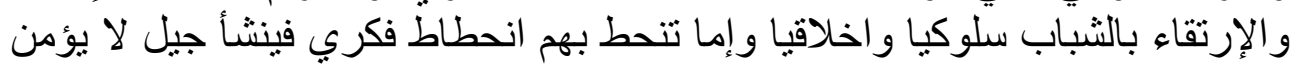

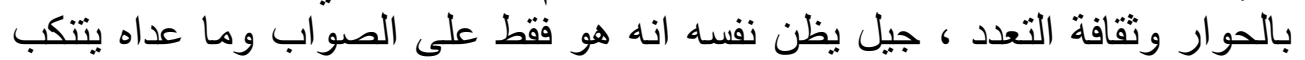

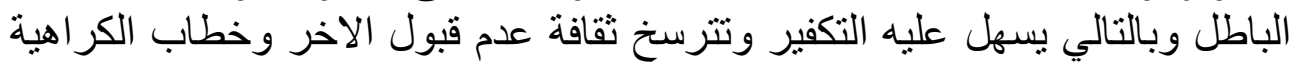

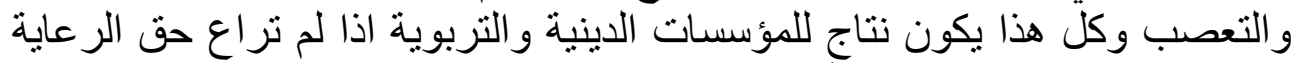

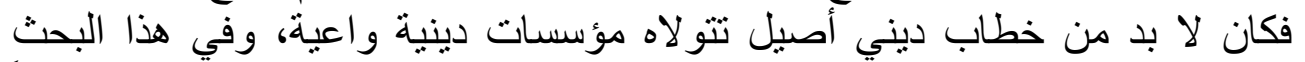

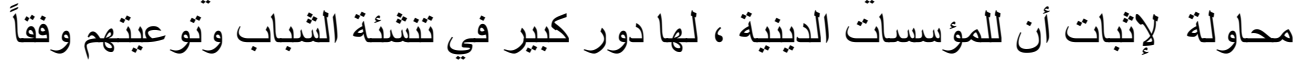

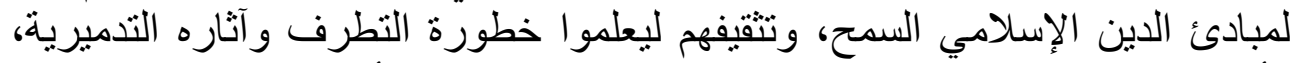

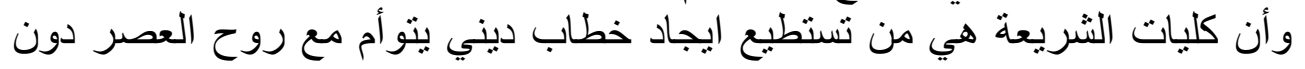


د /قيس سالم المعايطة د/ عقاب ذياب الطراونة

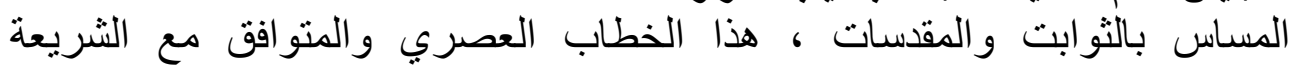

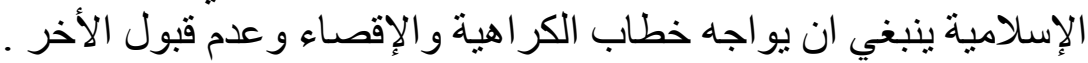

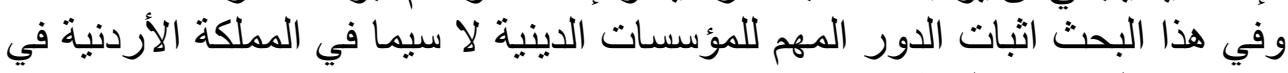

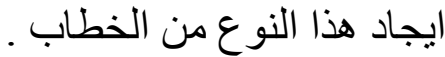
فكانت هذه الدراسة تتكون من ثناث الخطاد مباحث ، المبحث الأول كان في تحديد المفاهيم

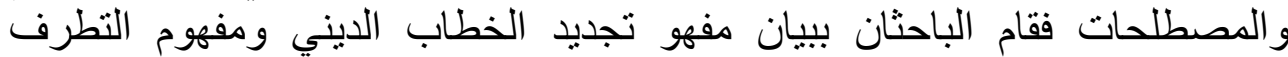
و الأرهاب و المصطلحات ذات الصلة ، وبيان الفرق بين الخطاب الثران الثر عي و الخطاب

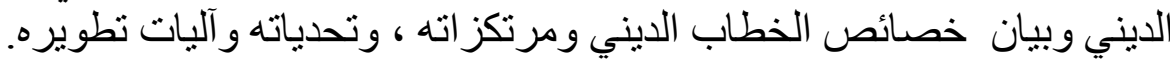

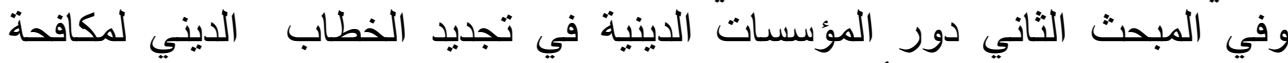
التطرّف ، في المطلّ الأول : دور المؤسسات الدينية) في تجديد الخطاب الدئ الديني

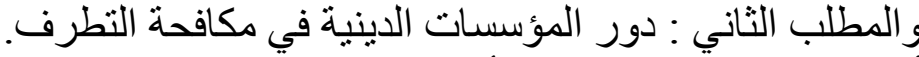

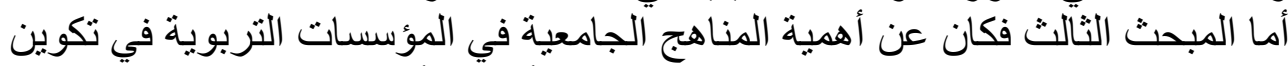

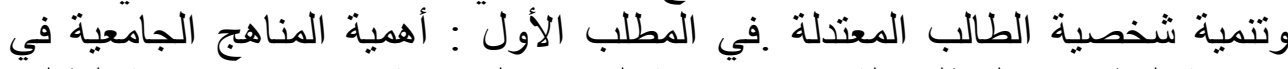

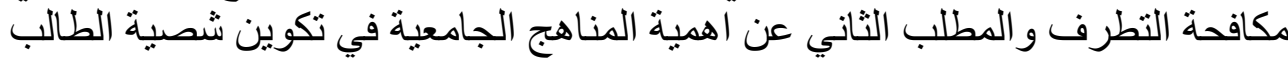

واخير ا كانت النتائج و التوصيات التي كان من ابرز ها ان للمؤسسات الدينية

$$
\text { الجامعي. }
$$

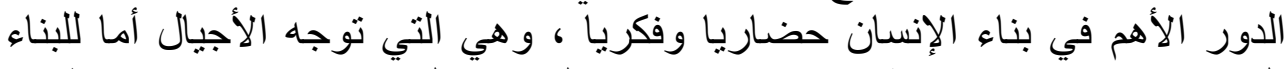

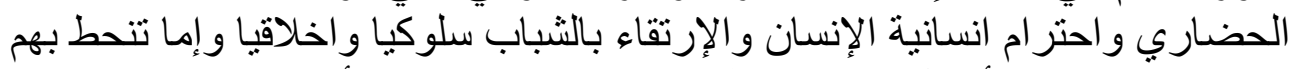

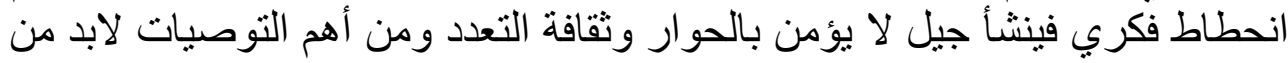

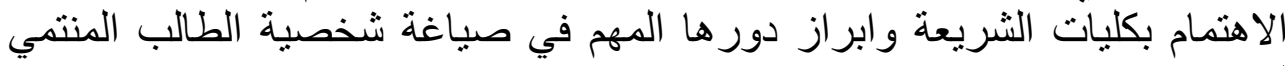

$$
\text { المبحث الأول }
$$$$
\text { لوطنه و امته . لونمات }
$$

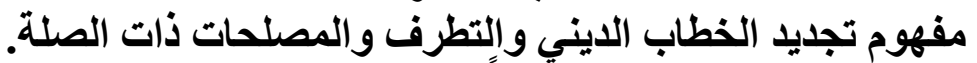

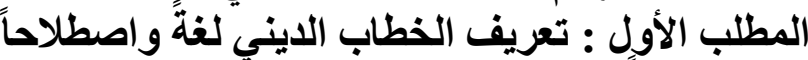

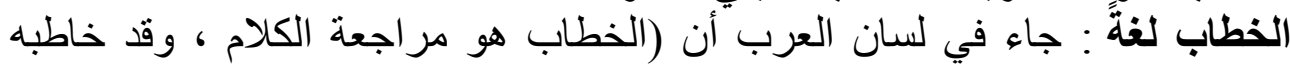

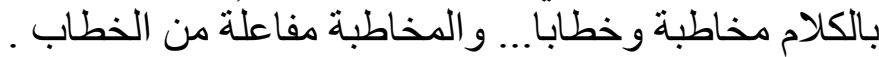

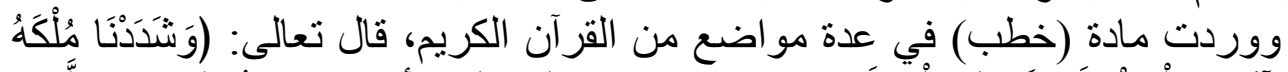

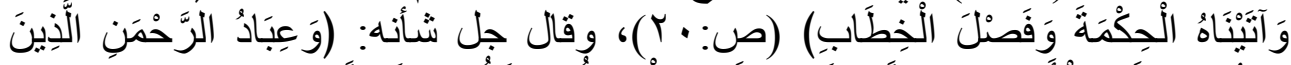

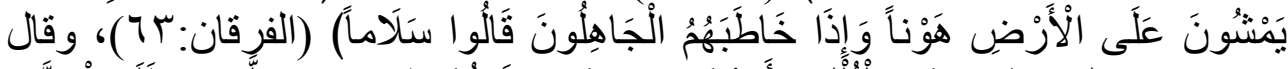

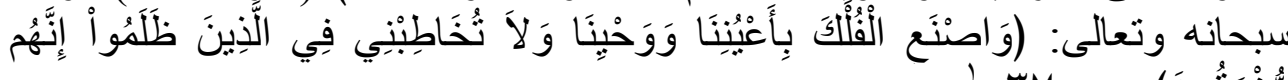

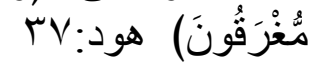

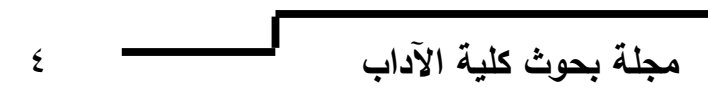


دور المؤسسات الاينية في تجديد الخطاب الايني

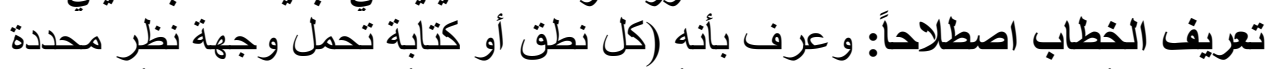

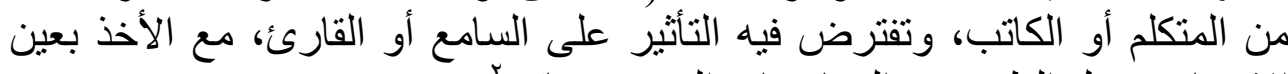

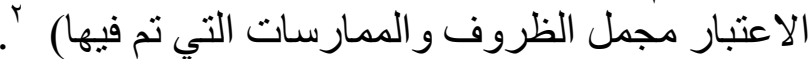

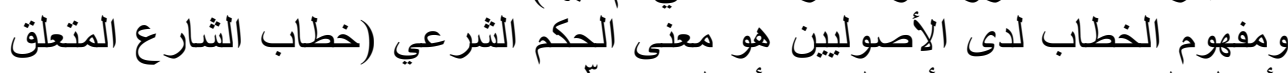

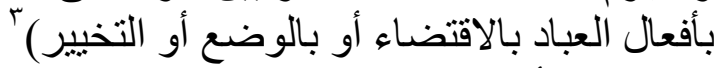

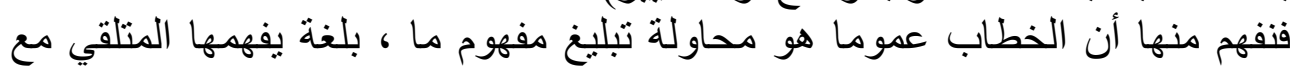
مر اعاة المستوى العلمي و الجغر افي و التنديني.

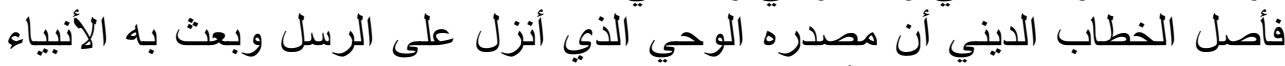

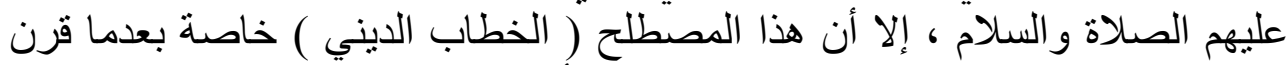

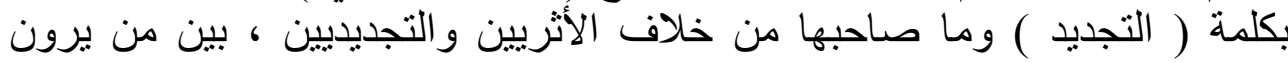

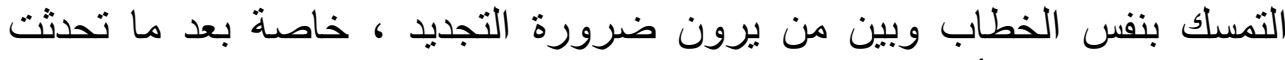

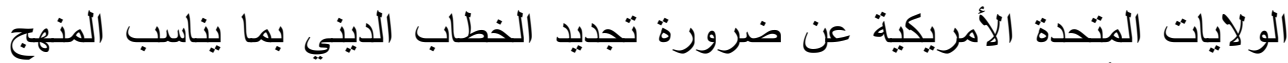

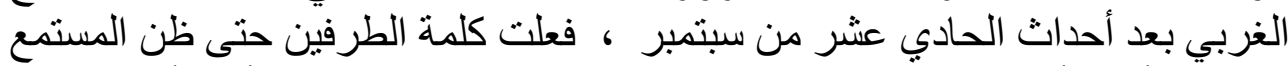

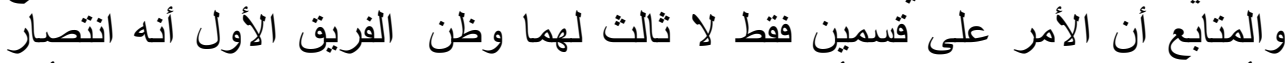

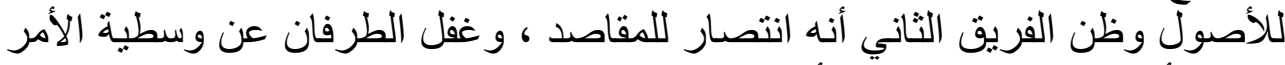

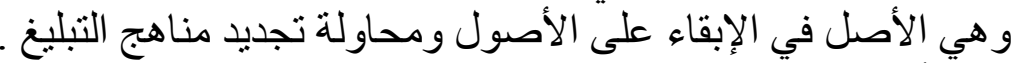

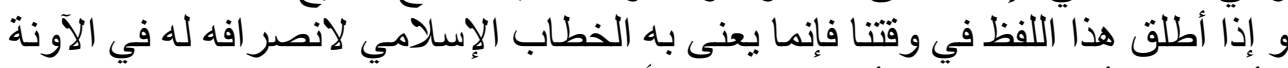
الأخيرة مع أنه يشمل كل الأديان السماوية.

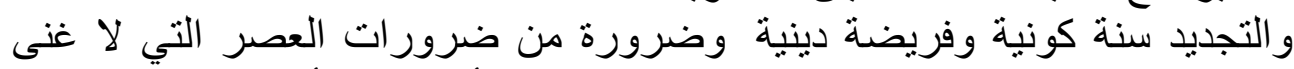

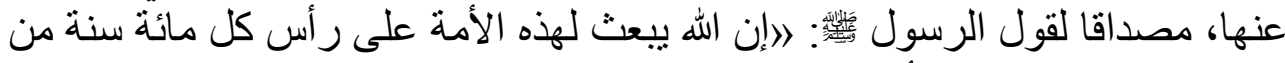

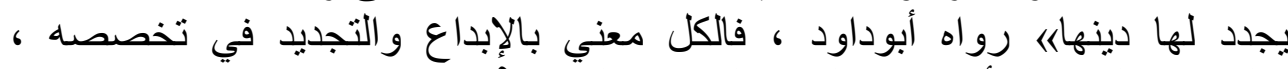

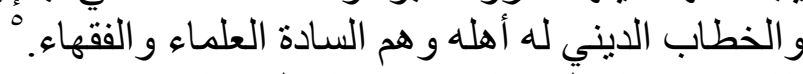
الفرق بين الخطاب الشرعي والخطاب الايني:

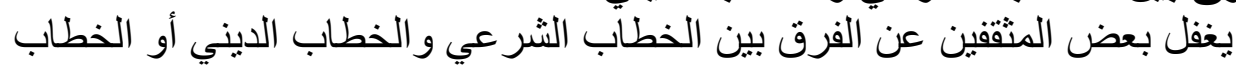

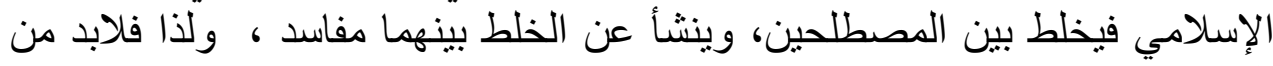

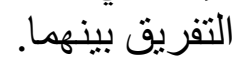

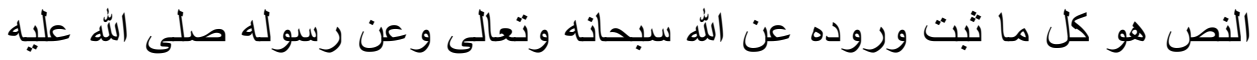

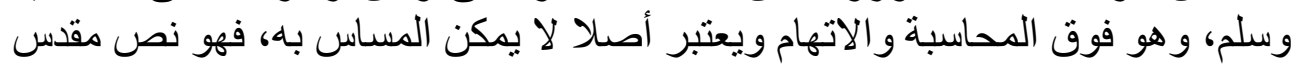

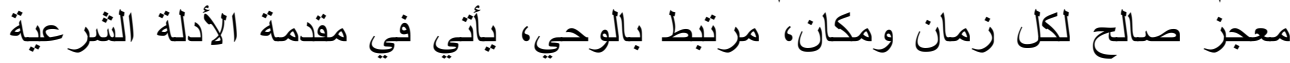

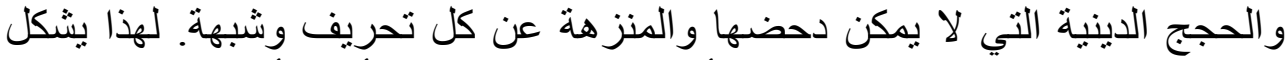

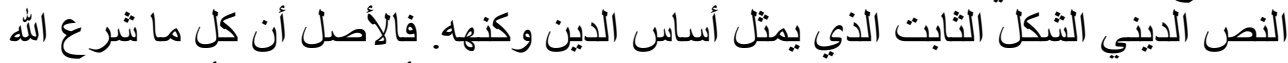

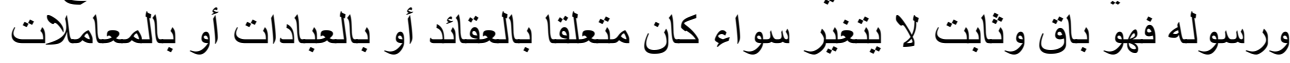

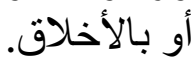


د /قيس سالم المعايطة د/ عقاب ذياب الطراونة

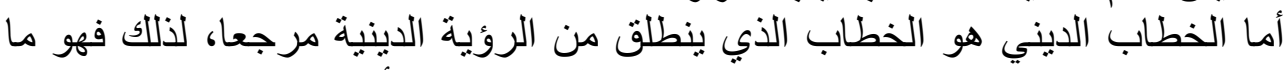

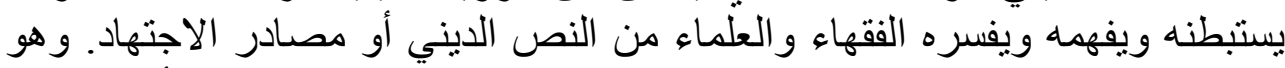

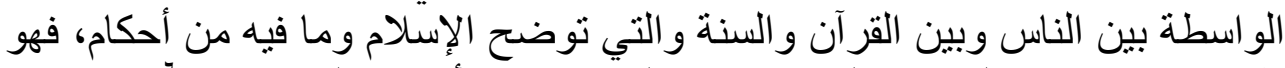

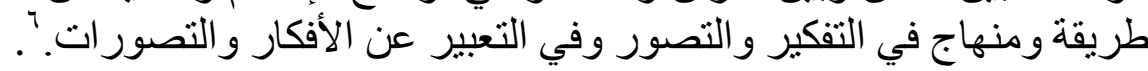

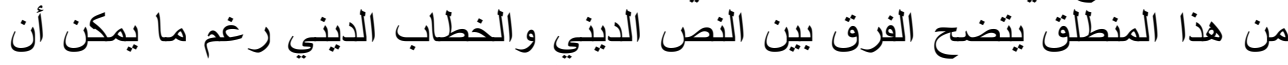

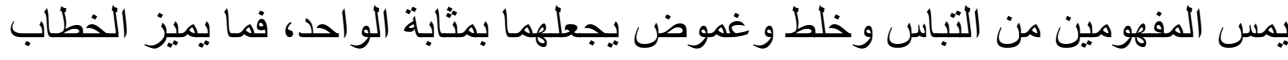

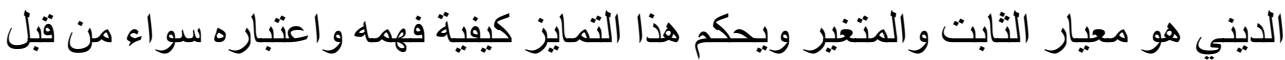

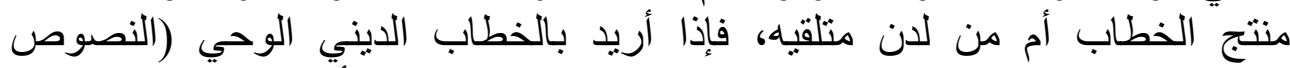

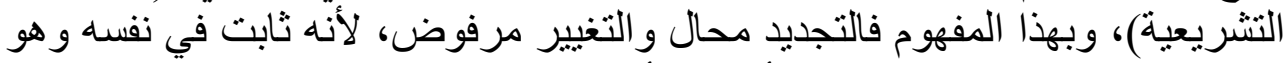

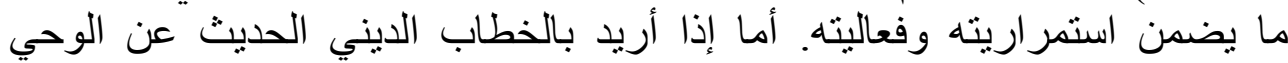

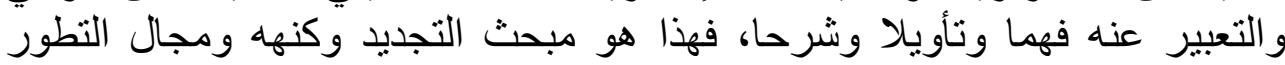

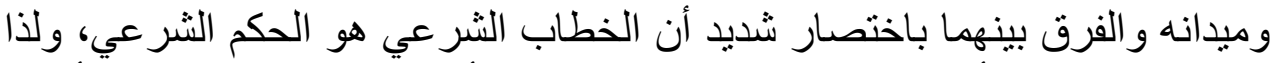
نجد علماء الفقه و أصوله يعرفون الحكم الثرعي بأنها خطاب خاب الله المتعلق بأفعال

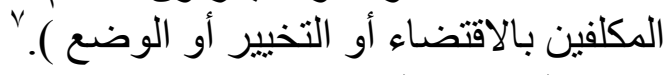

\section{التطرف اصطلاحا:}

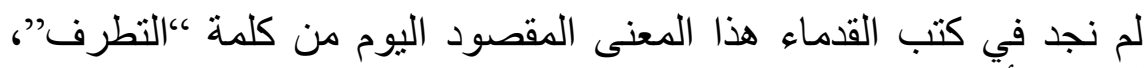

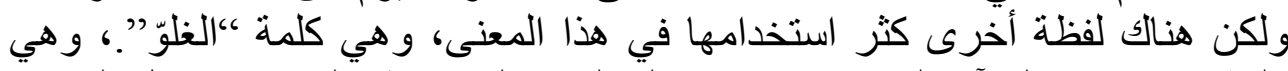

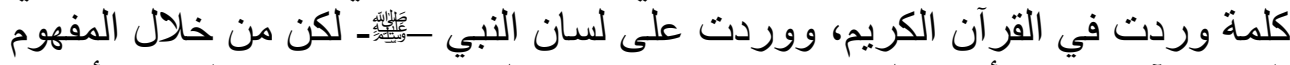

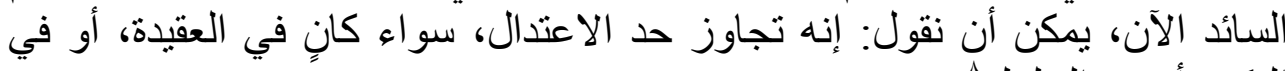

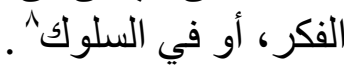

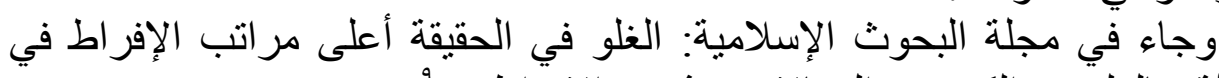

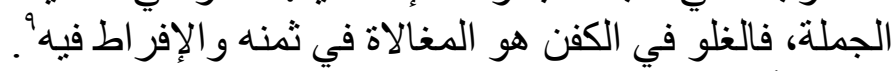

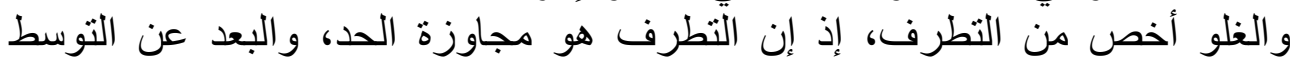

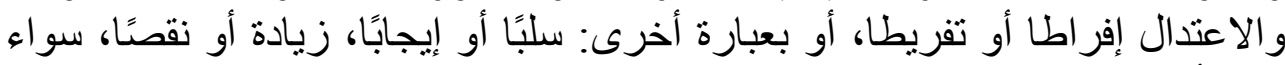

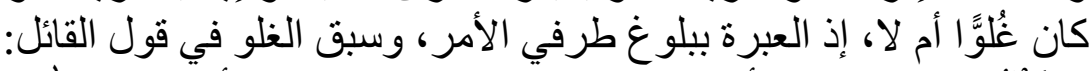

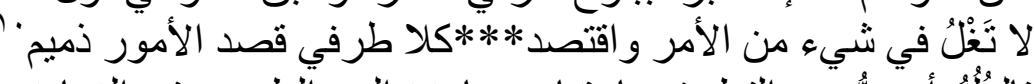

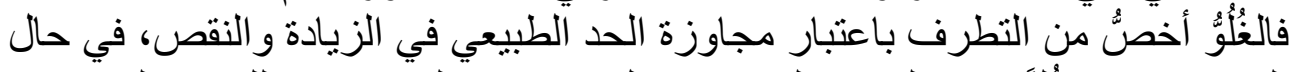

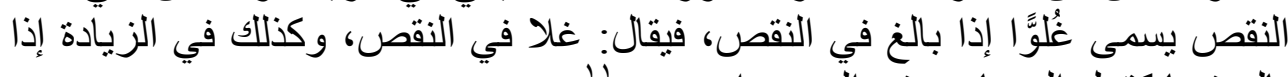

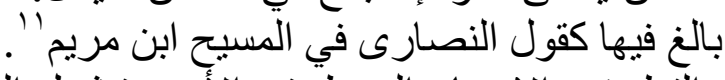

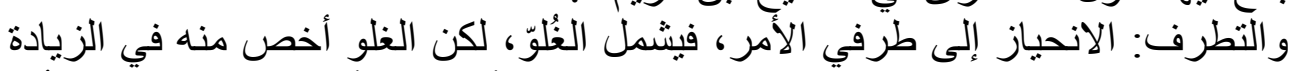

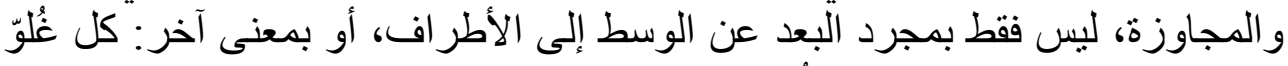
فهو تطرف، وليس كل تطرف لُّلوّة

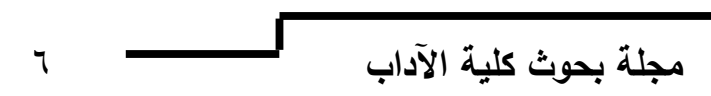


دور المؤسسات الدينية في تجديد الخطاب الديني

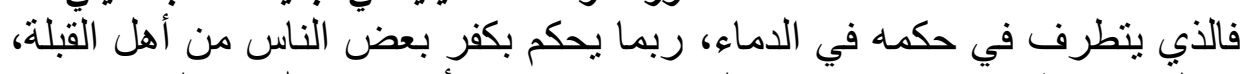

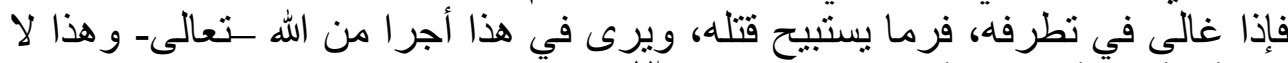

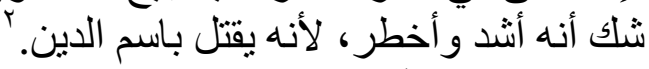

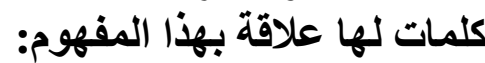

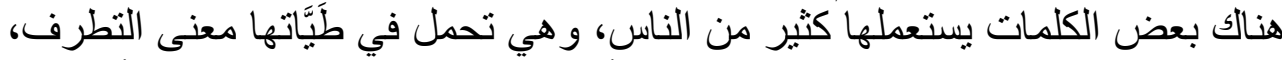
و إن كانت تختلف معها من حيث اللفظ، إلا أن معناها يكاد يكون وهي واحدا في أذهانهم،

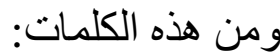

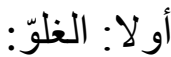

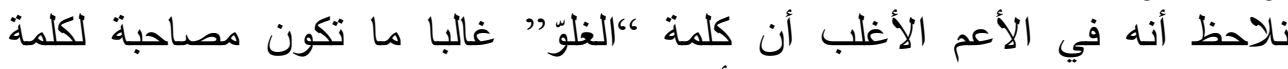

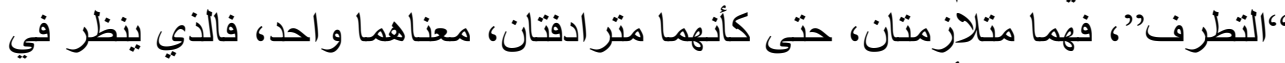

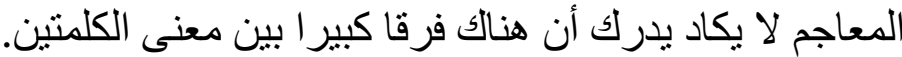

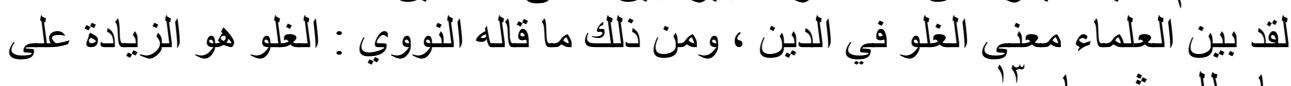

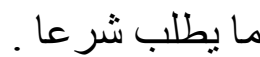
وقال ابن حجر : هو المبالغة في الثيء ، و التثديد فيه بتجاوز الحد ، وفيه معنى

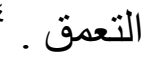
وقال المناوي : الغلو تجاوز الحد .

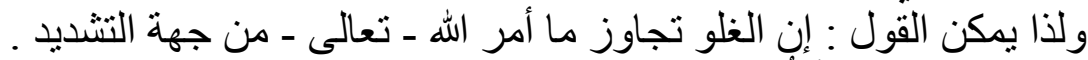

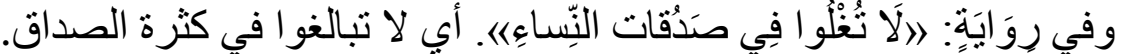

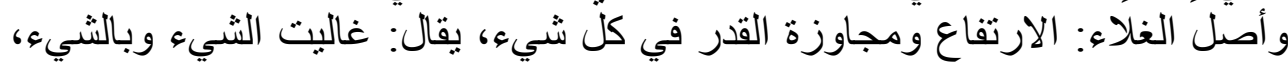

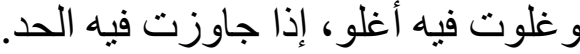

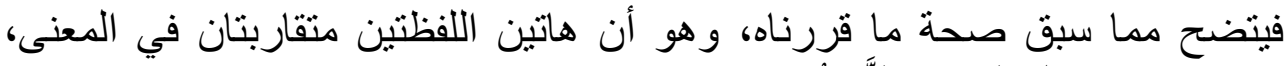

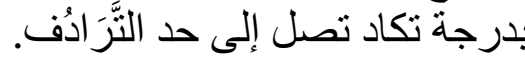

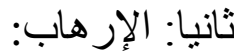

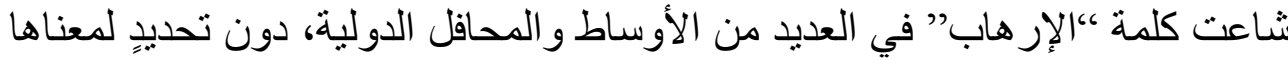

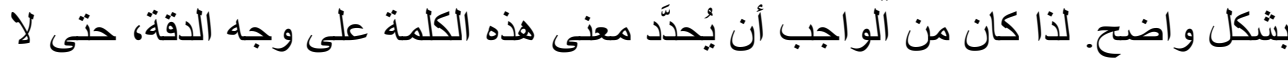

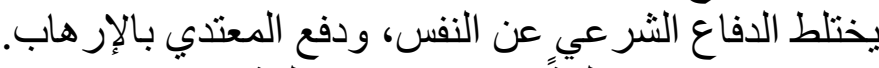

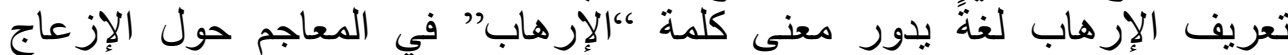

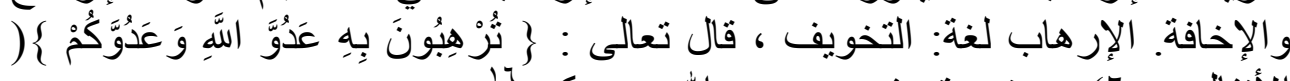

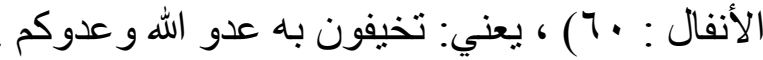
• • م تعريف الإرهاب اصطلاحًا:

فتعريف الإرهاب " بحسب الاتفاقيات العربية لمكافحة الإرهاب الموقعة في القاهرة

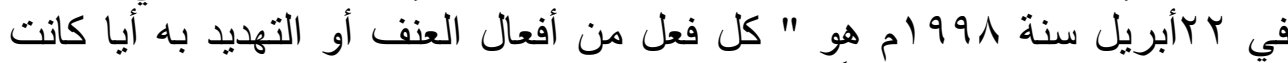
بو اعثه أو أغراضه يقع تتفيذاً لمشروع إجرامي فردي أو جماعي ويهدف إلى إلقاء التهاء 
د /قيس سالم المعايطة د/ عقاب ذياب الطراونة

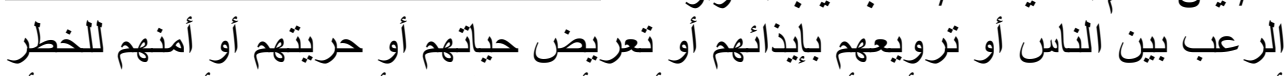

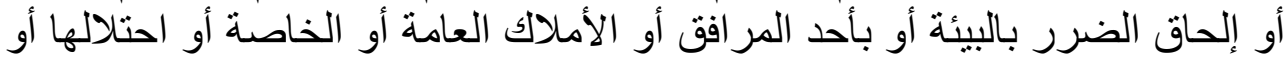

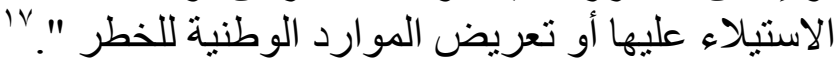

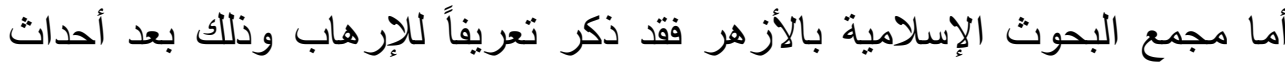

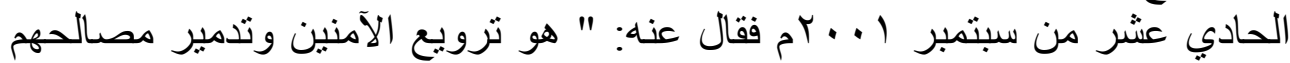

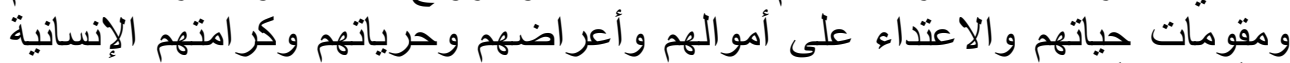

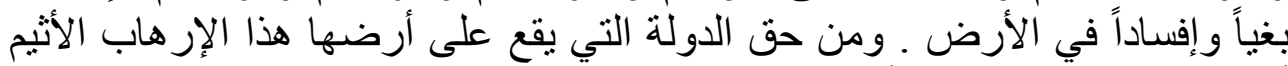

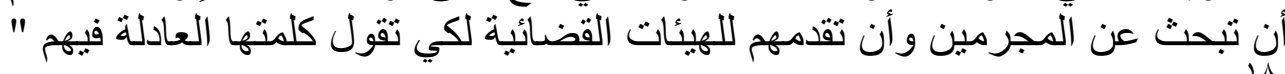
فيتضح مما سبق أن كلمة “،الإرهاب” تدل على التخاء التخويف والإفزاع، ويكون الأمر

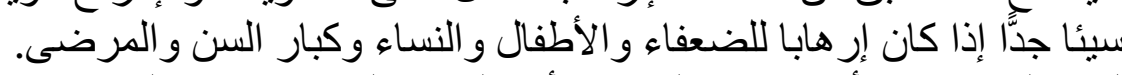

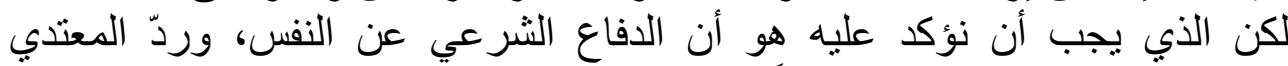

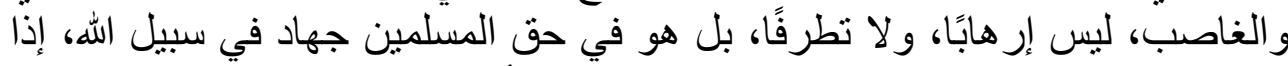

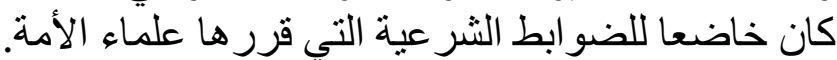

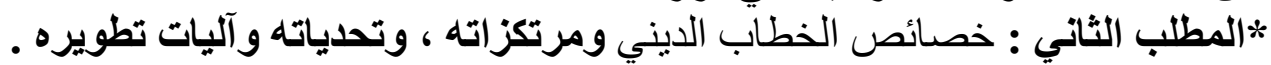

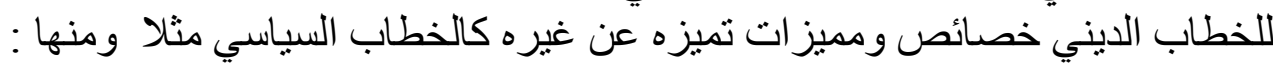

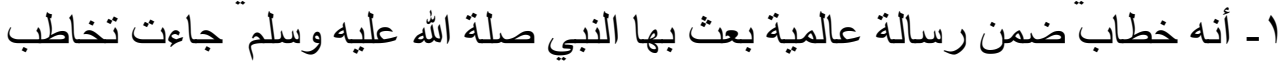

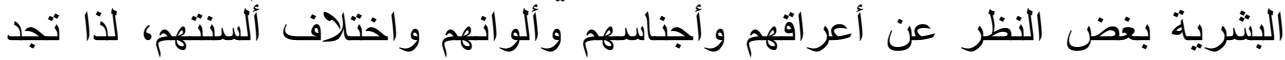

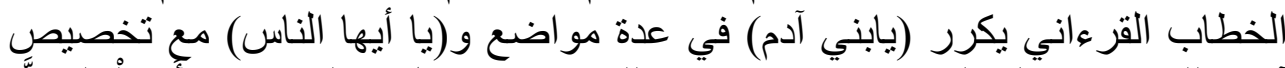

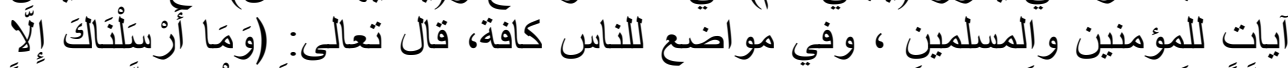

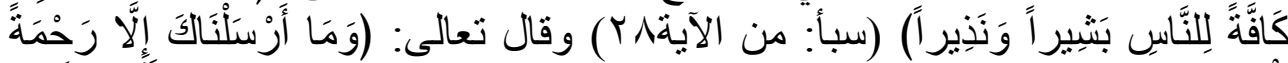

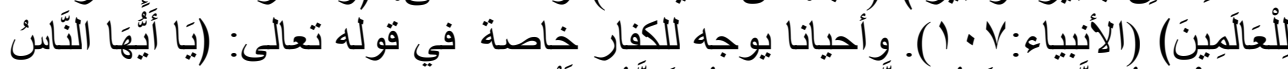

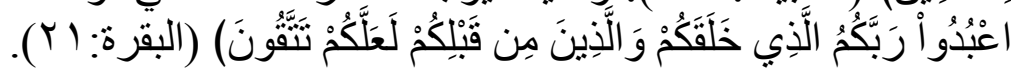

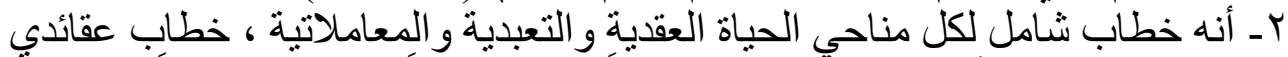

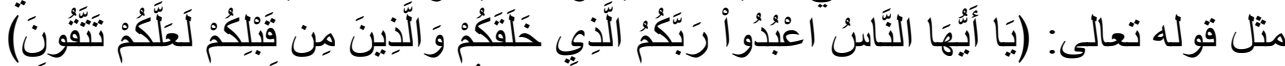

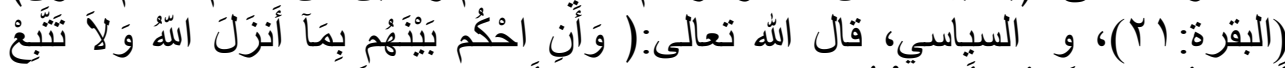

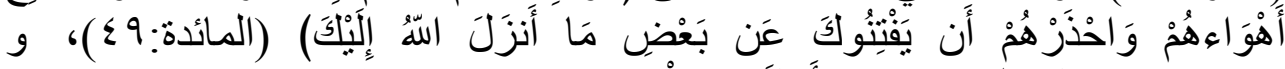

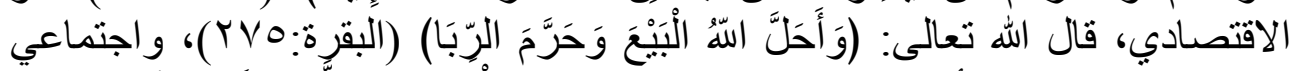

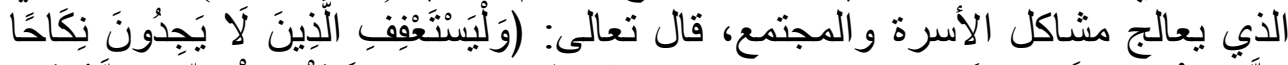

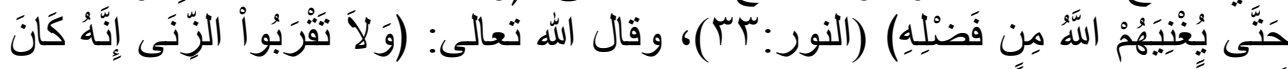

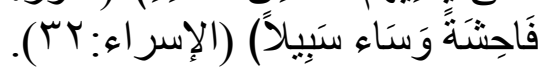

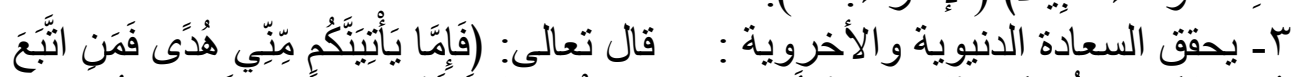

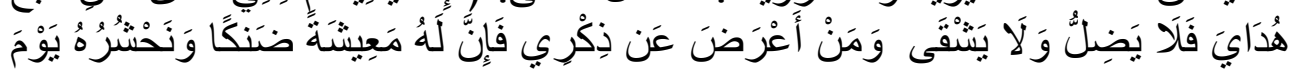




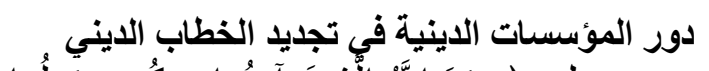

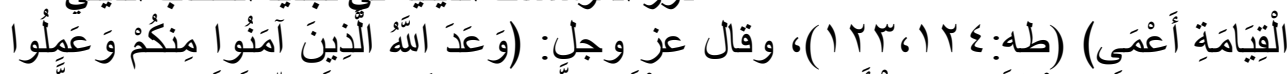

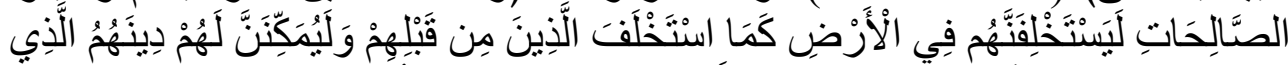

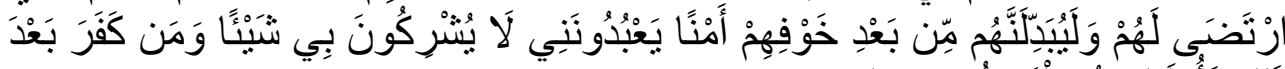

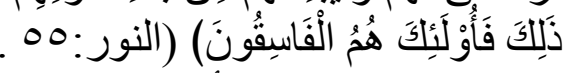

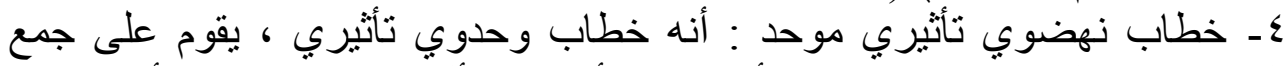

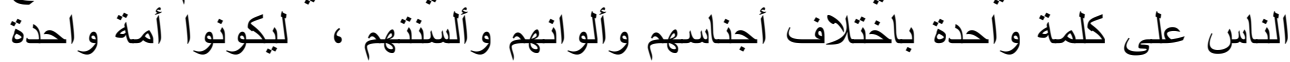

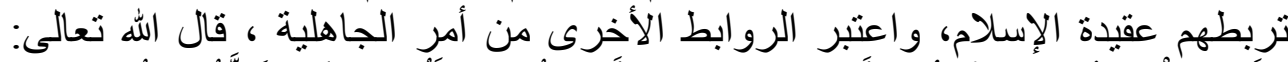

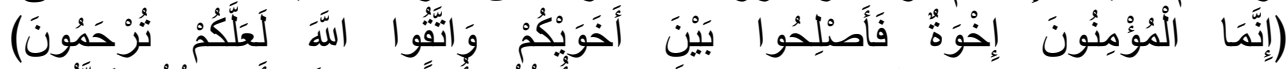

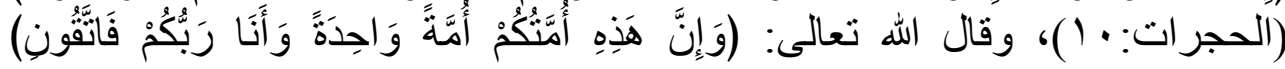

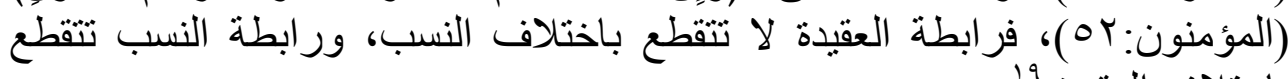
باختلاف العقيدة.

*رتنكز ات الخطاب الديني:

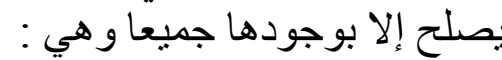

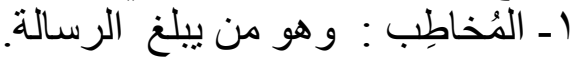
r ـ المخاطب:وهو المتلقي الذي توجّه لـ اله الرسالة ويستقبلها ويستو عبها.

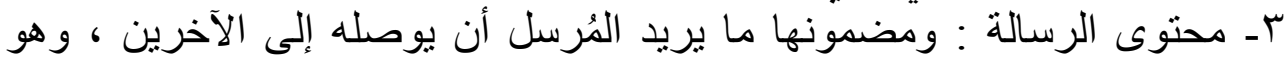
اساس الخطاب الديني

ع- وسيلة الاتصال : فالخطاب يكون شفويا أو مكتوبا ، وقد تستغل وسائل الإعلام

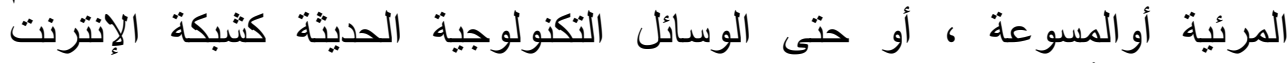

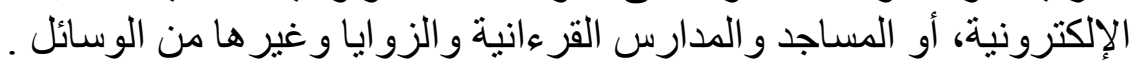

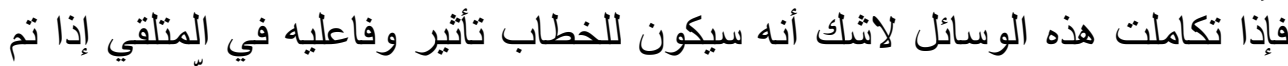

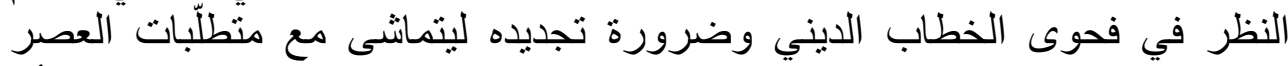

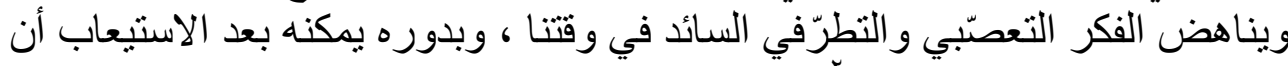

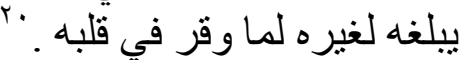

\section{*تحديات الخطاب الديني ومعوقاته:}

1 أـ الإلحاد: أو اللادين وهو من أكبر التحديات التي ثُؤجَّهه الخطاب الديني خاصة

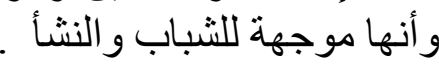


د /قيس سالم المعايطة د/ عقاب ذياب الطراونة

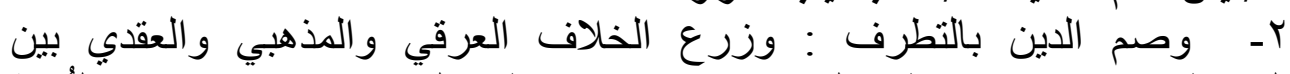

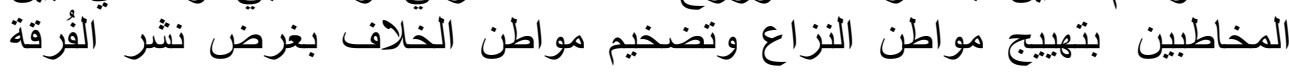

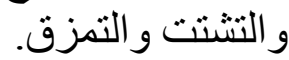

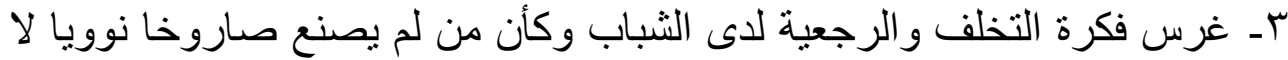

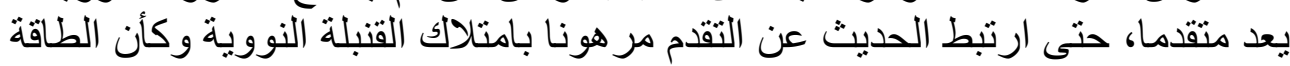

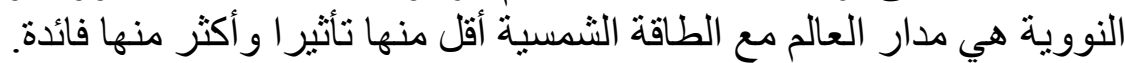

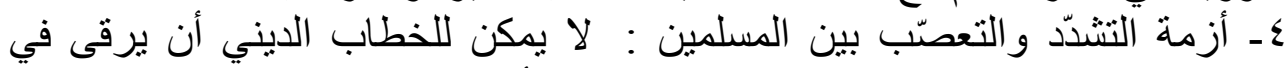

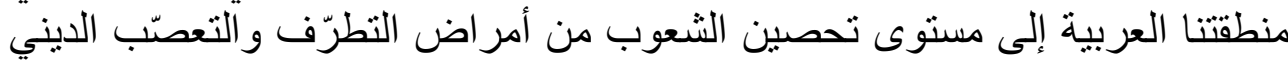

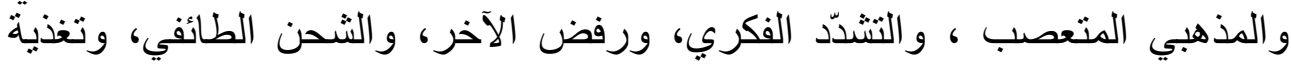

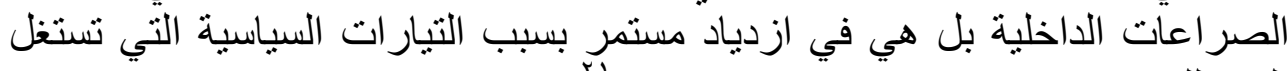

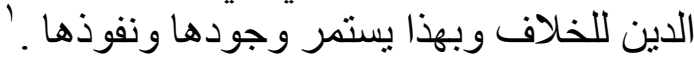

**آليات تطوير الخطاب الديني:

قد تكون مشكلة الخطاب الديني اليوم في الخلل في معادلة الدعوة و العمل الإسلامي ،

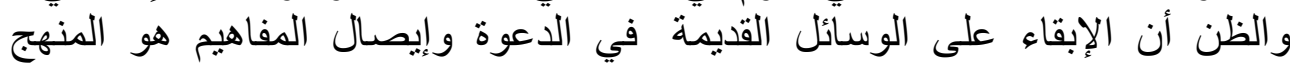

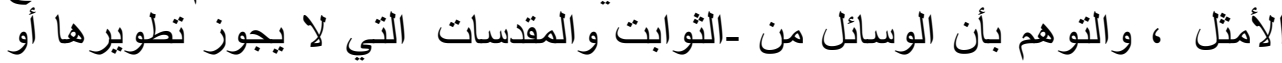

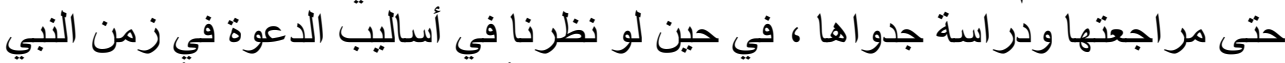

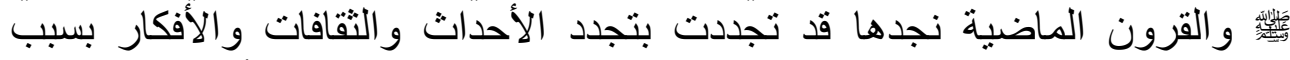

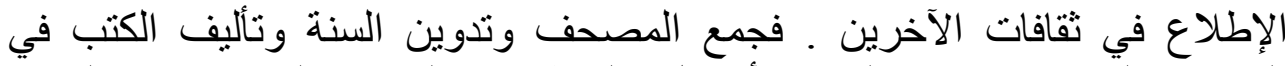

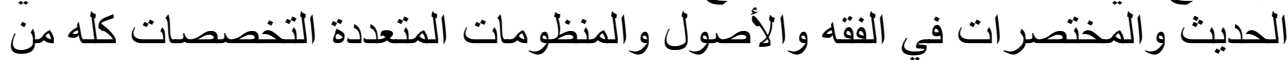

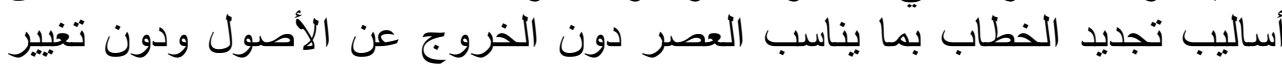

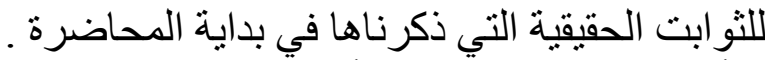

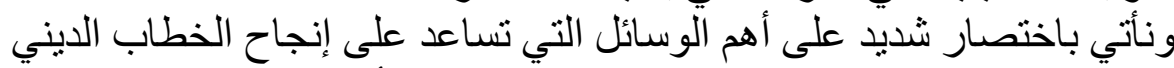

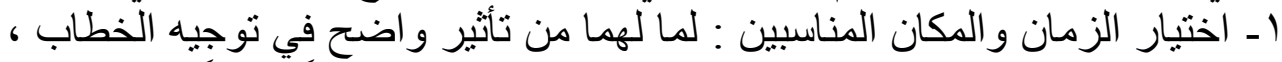

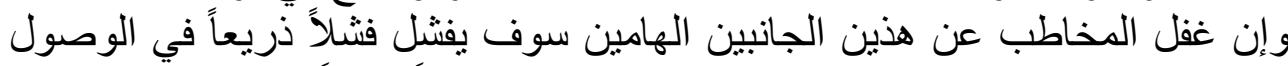

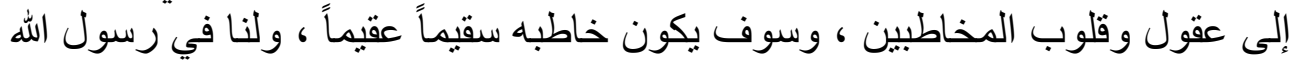

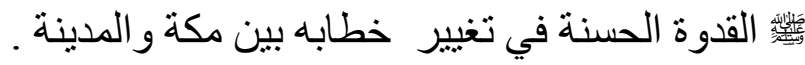

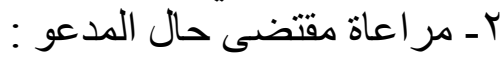

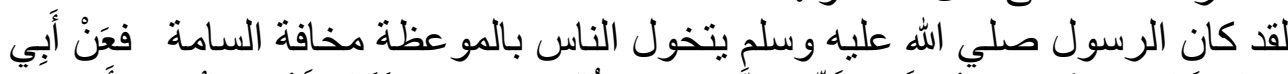

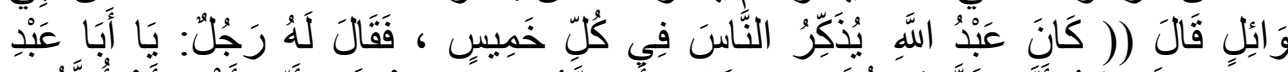

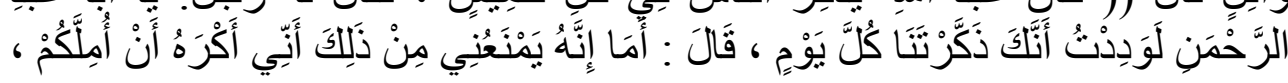

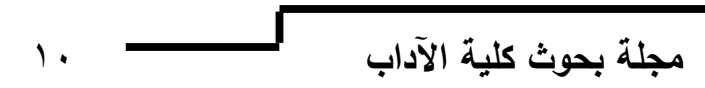




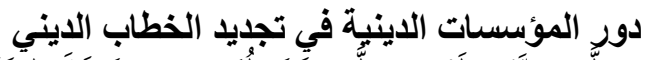

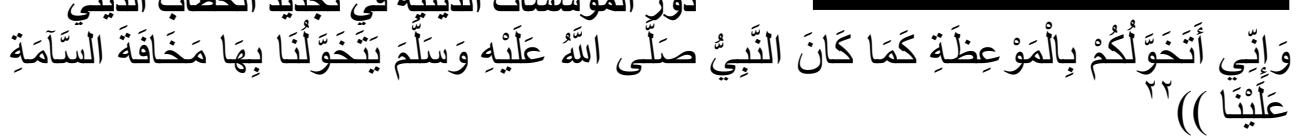

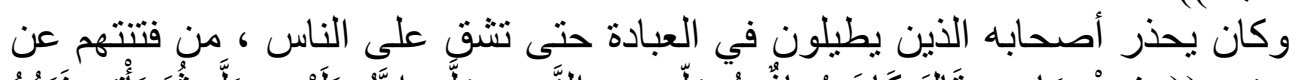

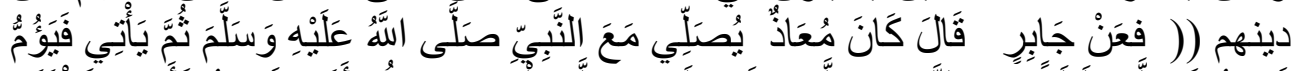

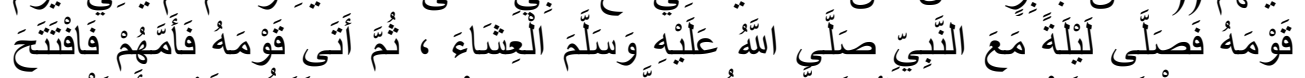

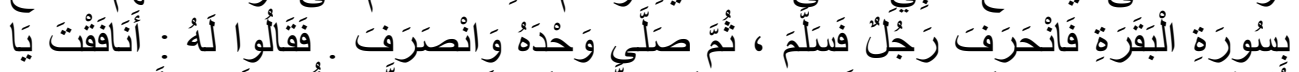

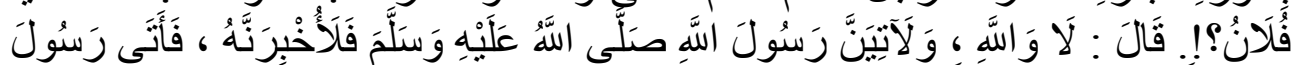

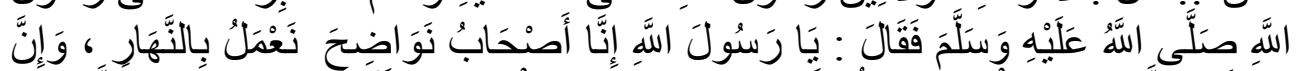

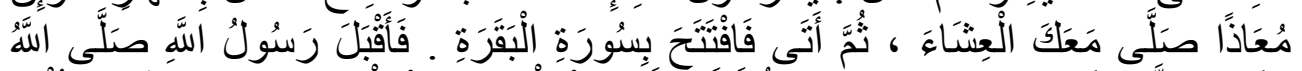

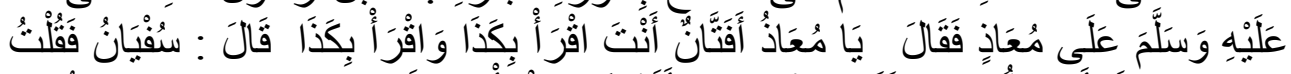

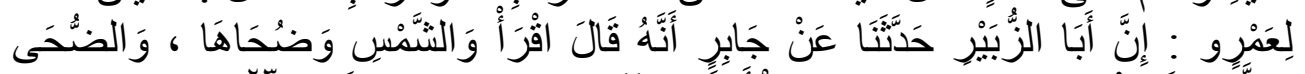

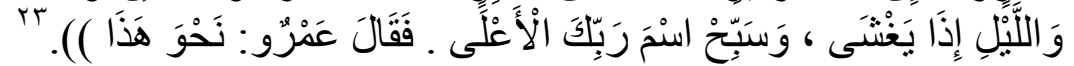

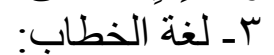

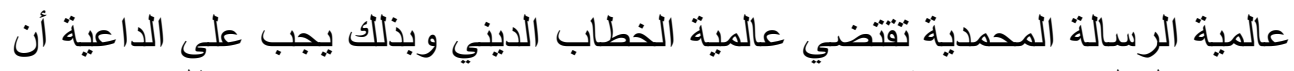

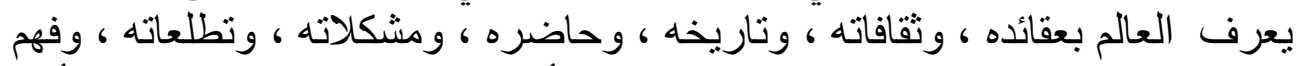

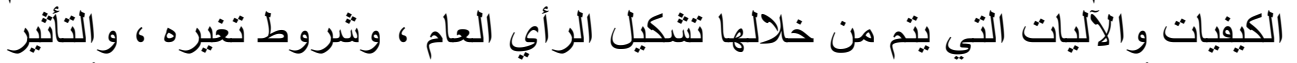

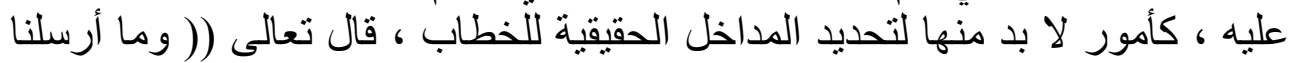

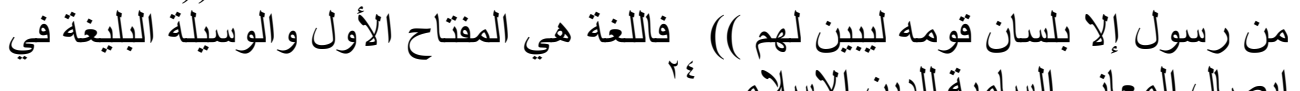

\section{المبحث الثاني}

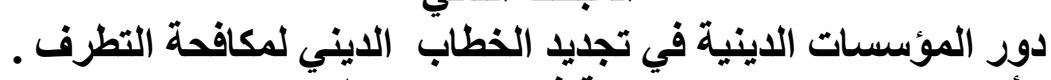

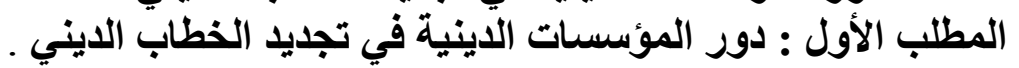

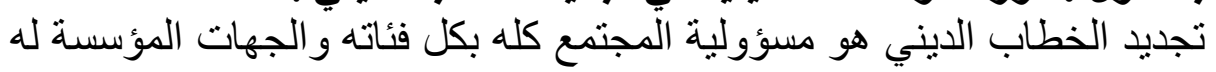

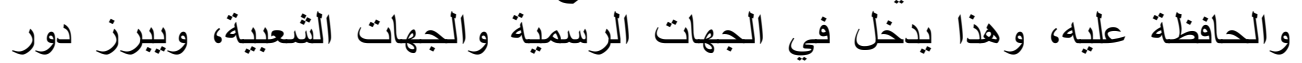

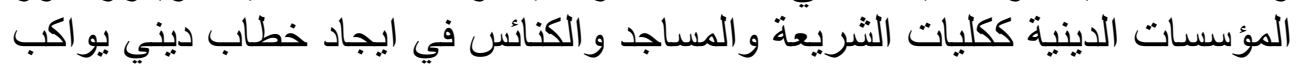
روح العصر ويرتني بالأمة.

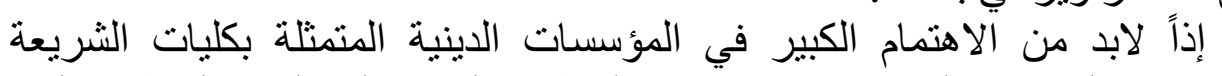

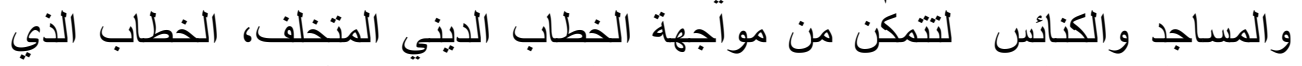

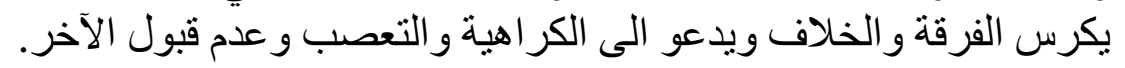

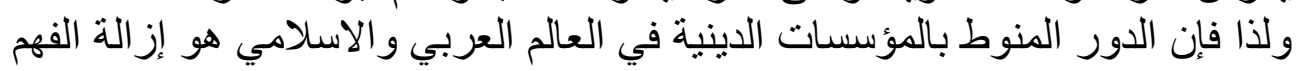
الخاطئ للاسلام وتجديد الخطاب الديني. 
دـ /قيس سالم المعايطة د/ عقاب ذياب الطراونة

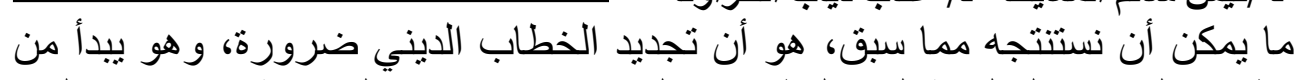

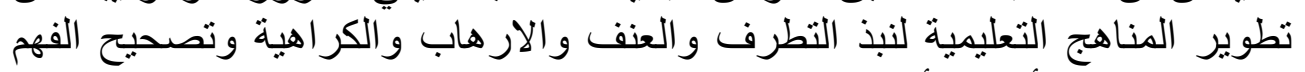

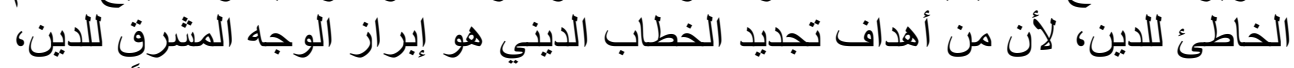

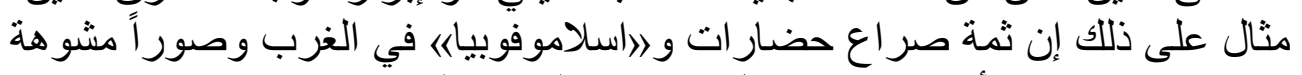

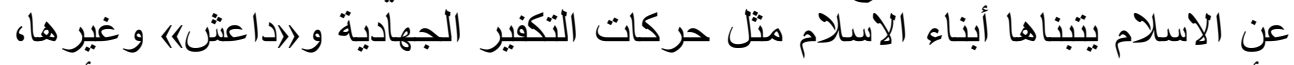

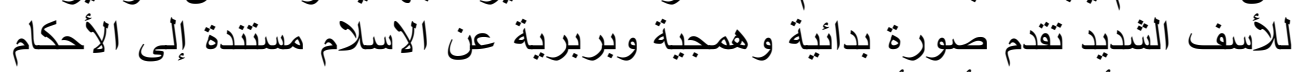

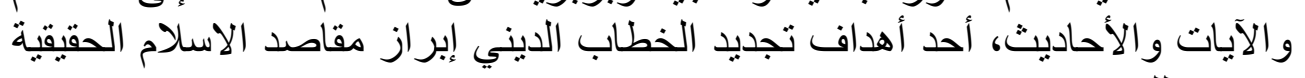
وتبيانها للناس. وأبرز هذه المقاصد - كما يراها كثير من الباحثين- تتمثل في الحرية الإنسانية

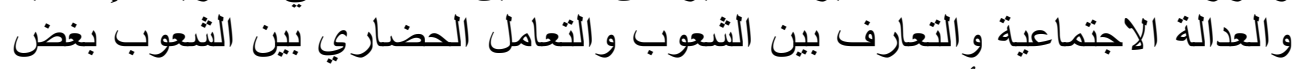
النظر عن اختلاف الأديان.

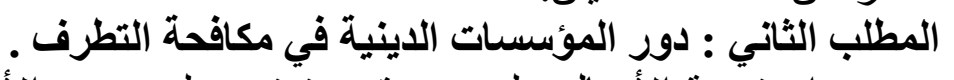

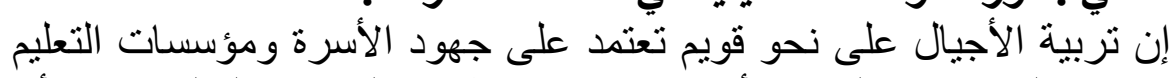

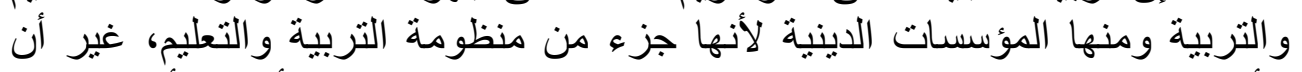

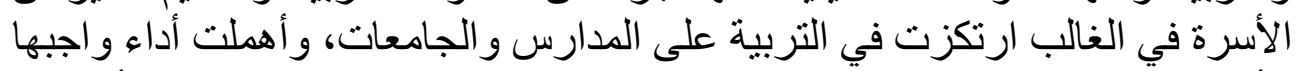

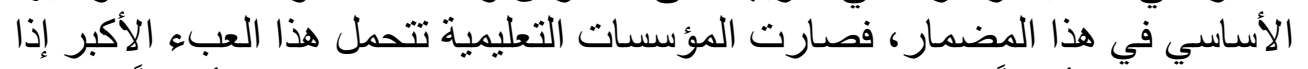

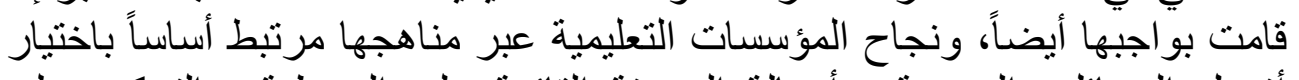

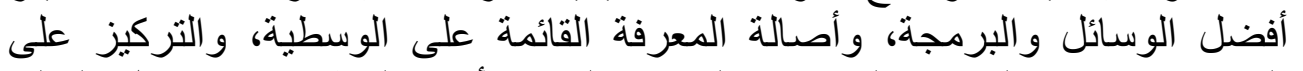
الغايات، و إعداد المناهج المدرسية المناسبة لجميع أبناء الوطن في مراحلة المبلة التعليم المختلفة.

و المؤسسات التربوية ( المدارس و المعاهد و الجامعات) منها اليوم ما هو قويم

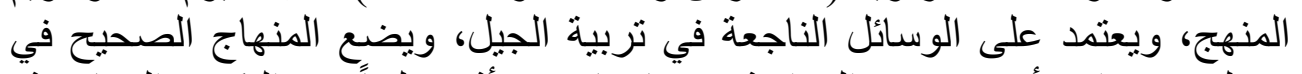

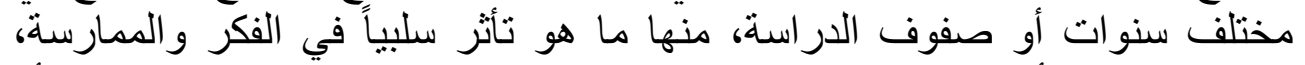

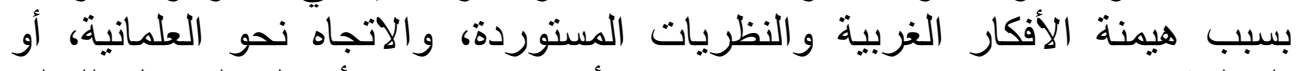

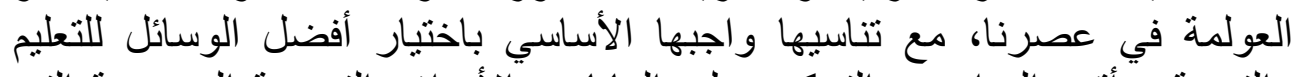

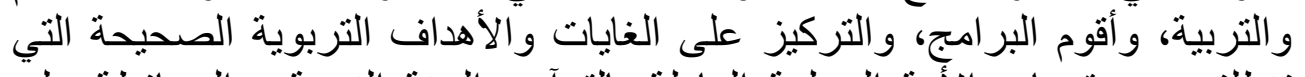

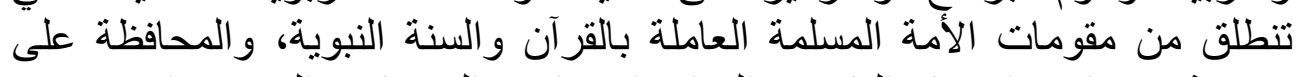

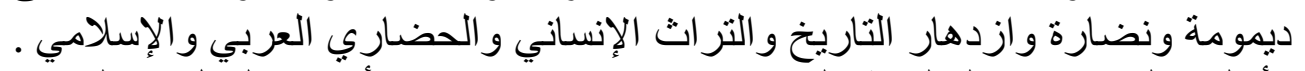

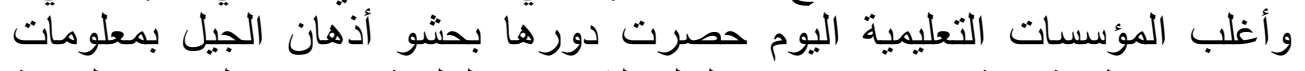

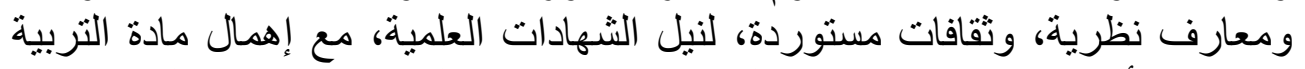

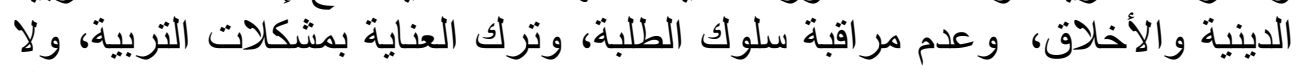
سيما في مرحلة المراهقة، وإبعاد ساحة العبادات و الفرائض الإسلامية الإية عن مجال التطبيق العملي .

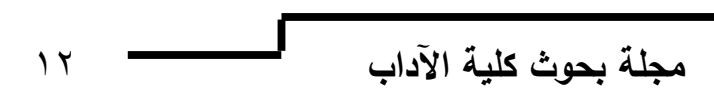


دور المؤسسات الدينية في تجديد الخطاب الايني

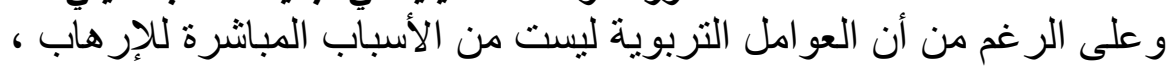

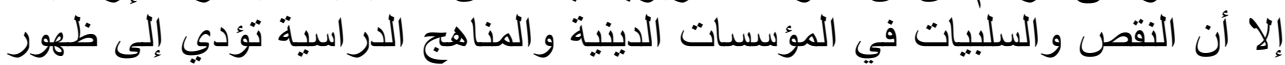

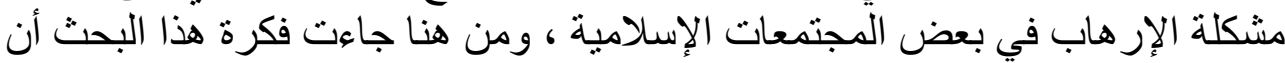

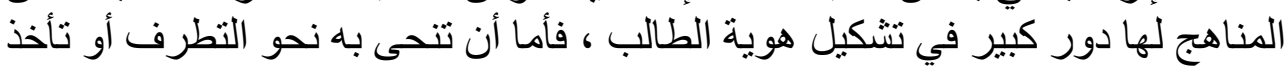

بيده نحو الاعتدال و العقلانية.

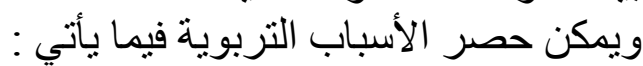
ا ـ نقص الثقافة الدينية في المناهج التعليمية من الابتدائي وحتى الجامعة في معظم

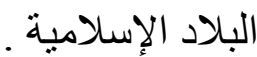
فما يدرس في مر احل التعليم الأساس ، لا يؤ هل شخصا مثقفا بثقافة مناسبة من الناحية

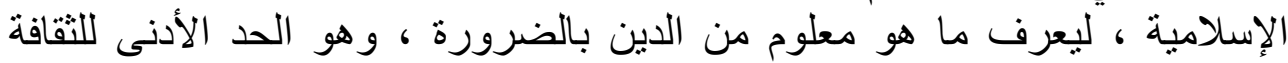

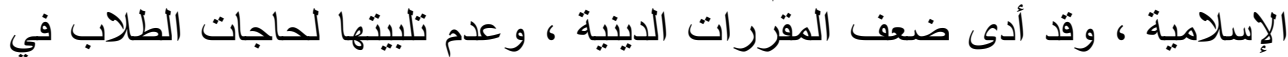

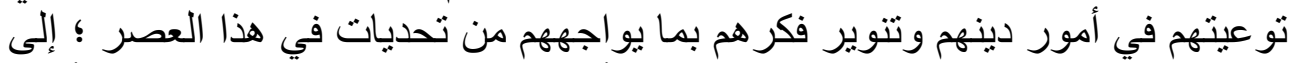

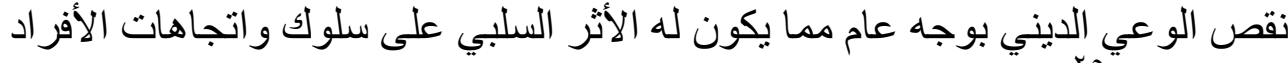

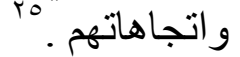
r ـ عدم الأهتمام الكافي بإبر از محاسن الدين الإسلامي والأخلاق الإسلامية التي يحث

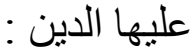

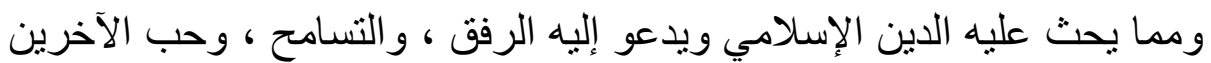

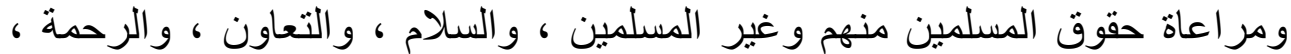

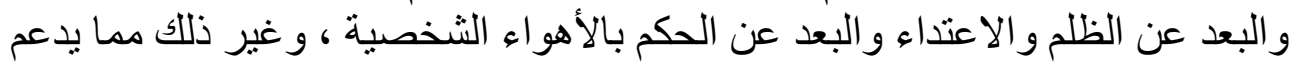

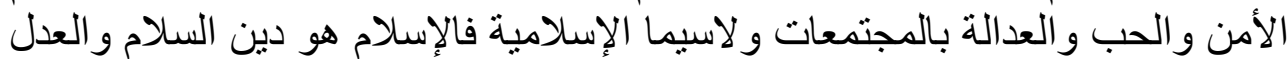

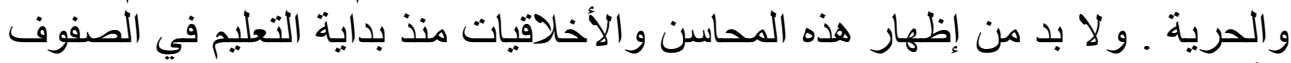

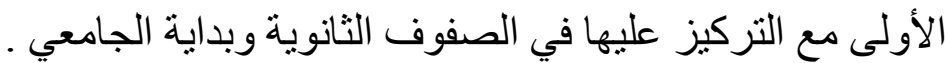

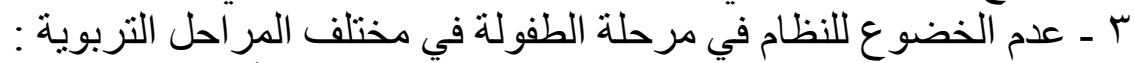

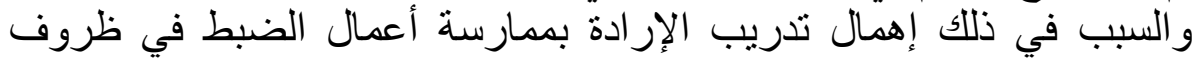

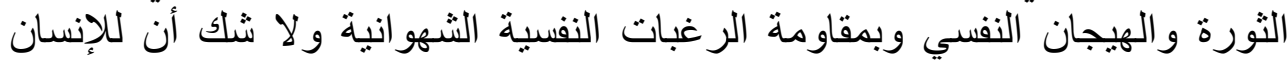

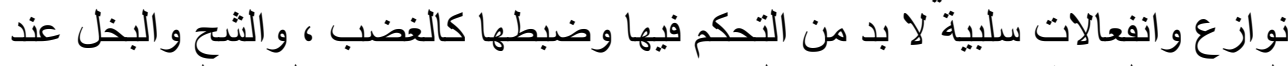

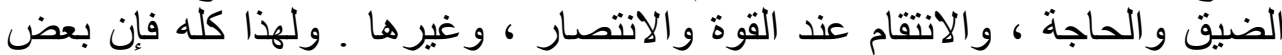

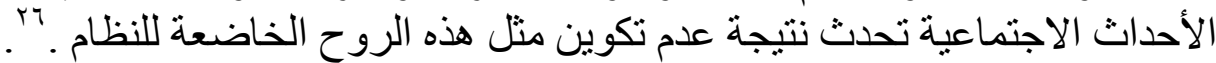

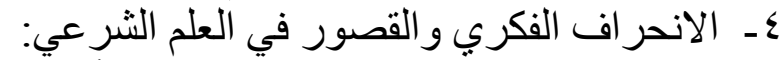

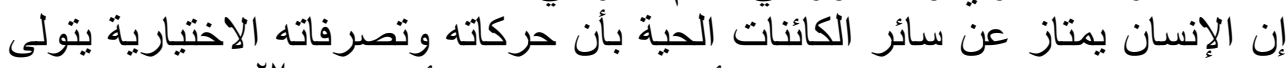

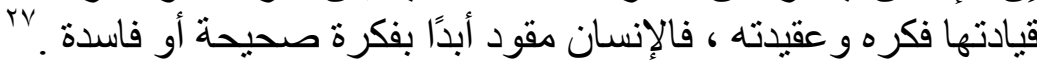

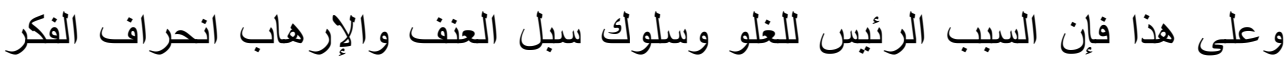

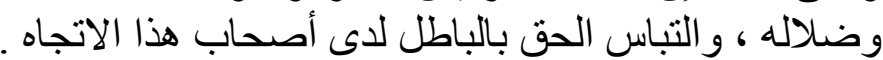




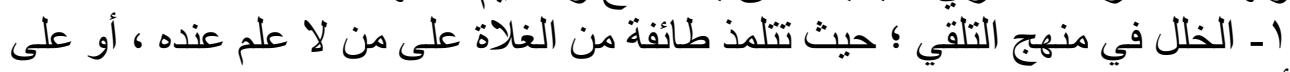

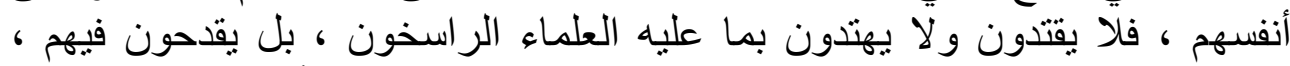

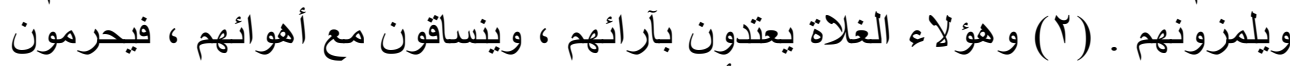

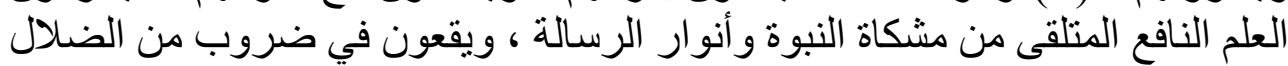

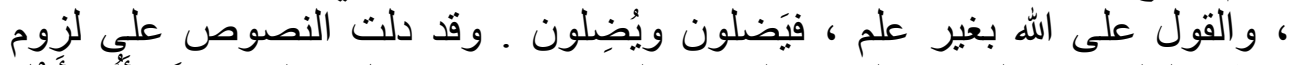

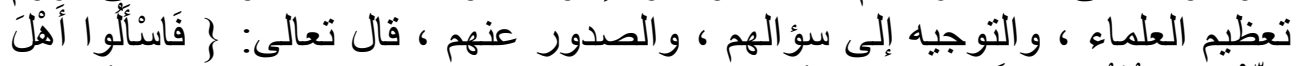

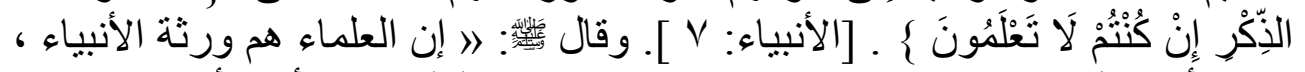

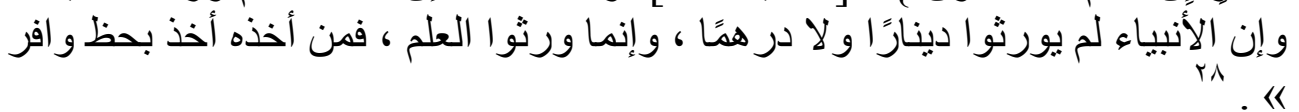

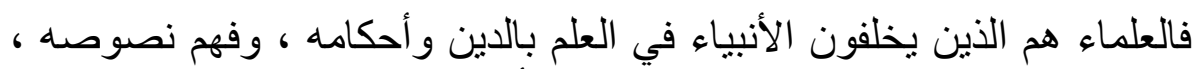

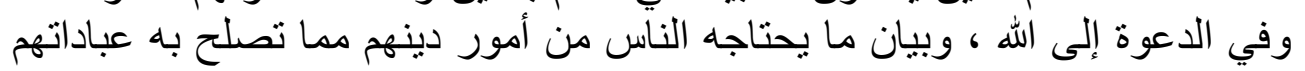

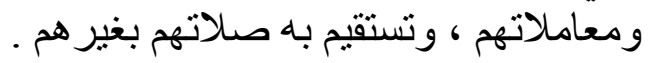

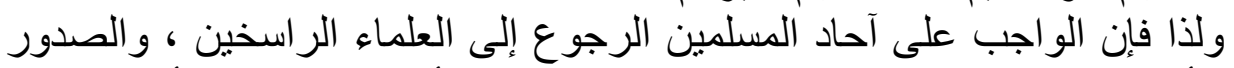

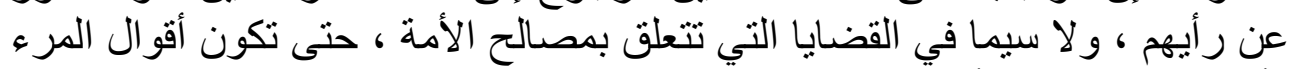

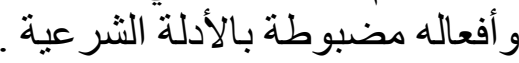

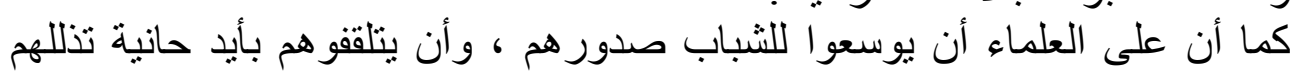

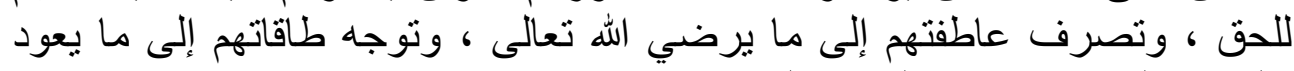

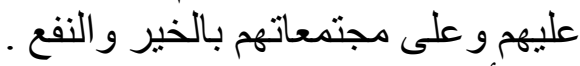

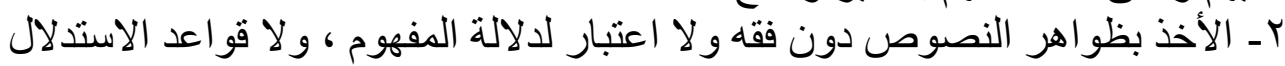

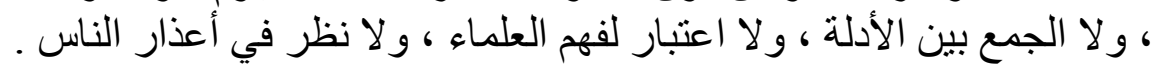

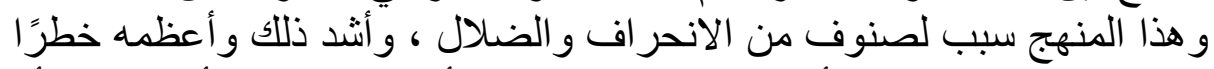

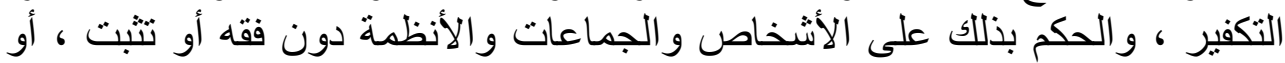

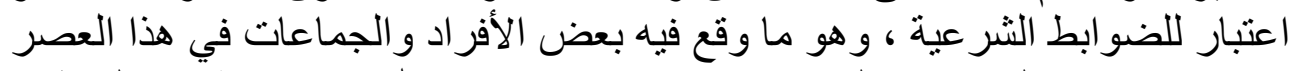

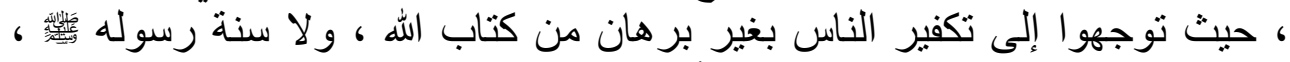

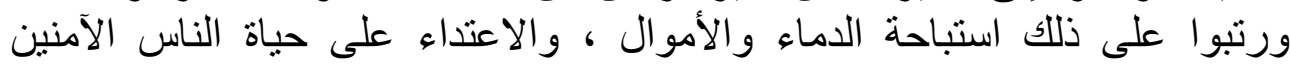

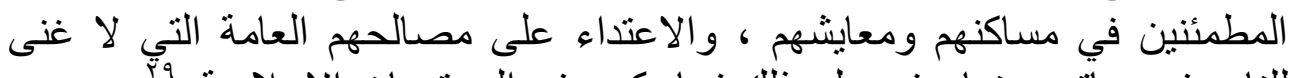

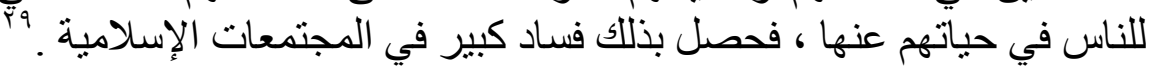

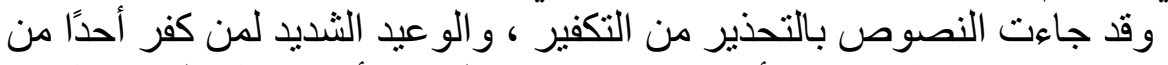

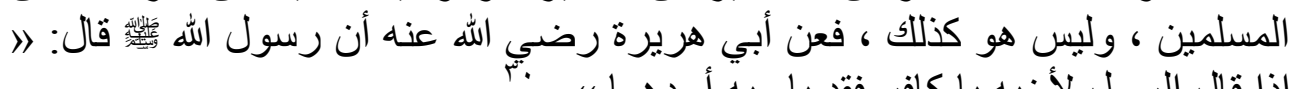

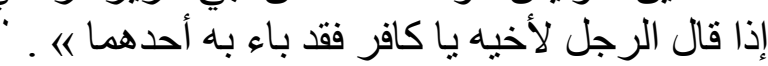

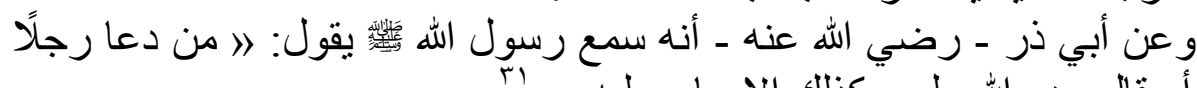

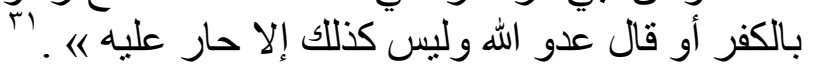


دور المؤسسات الدينية في تجديد الخطاب الايني

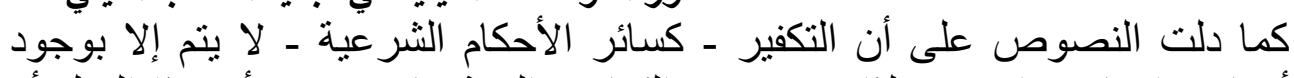

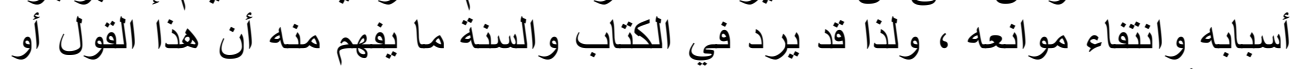

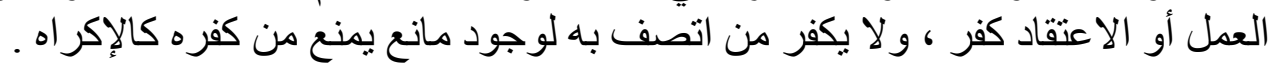

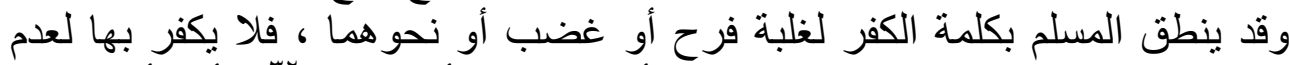

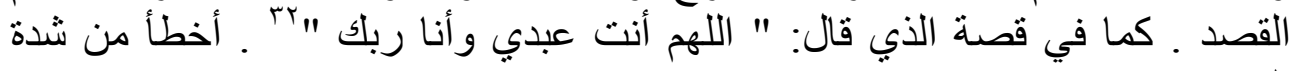
الفرح الفي

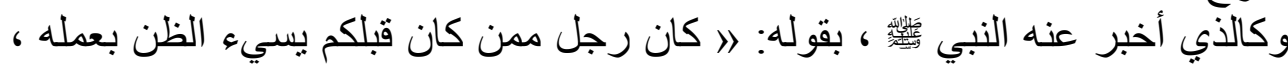

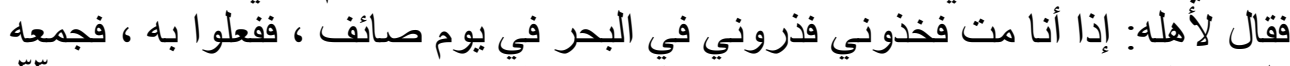

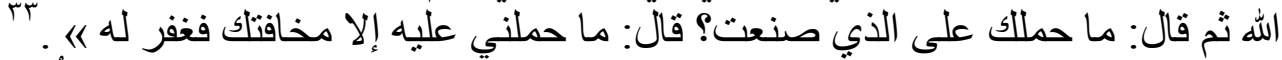

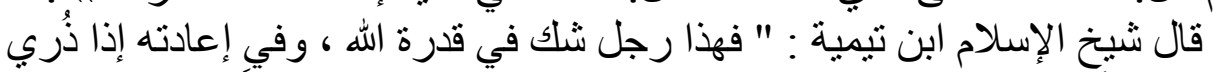

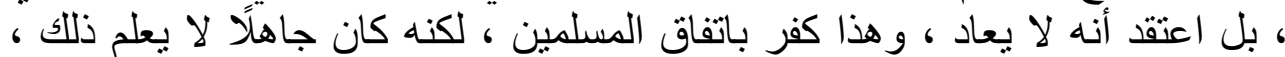

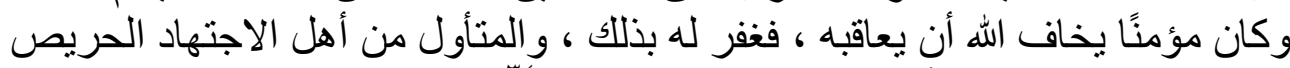

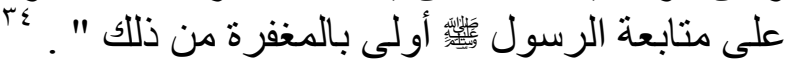

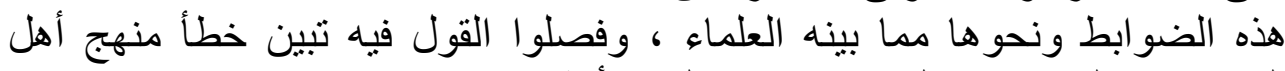

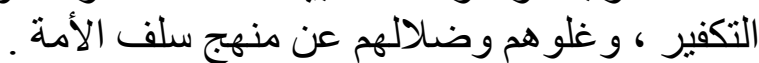

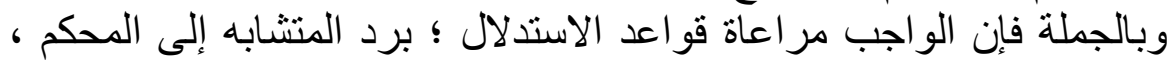

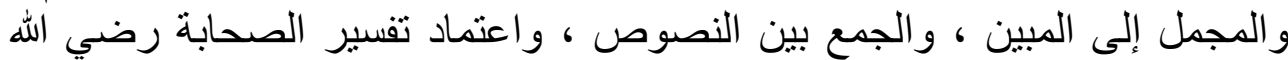

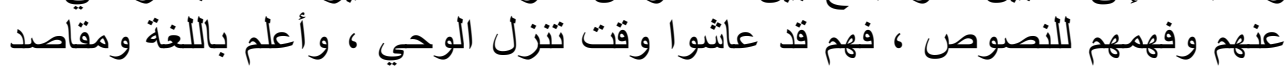

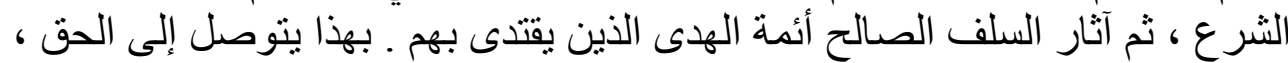
وتحصل السلامة من الزيغ و الضلال الضل .

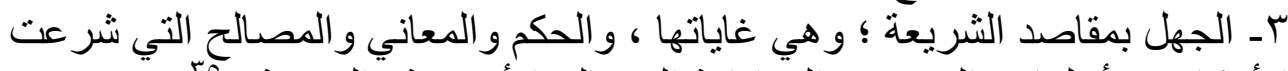

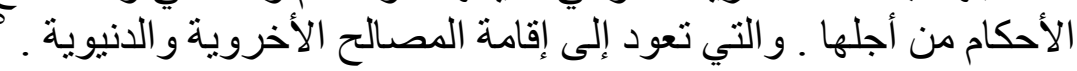

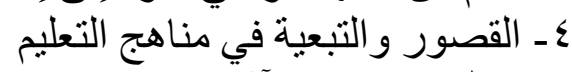
لقد كان من آثار الاستعمار والتغرئ التعريب أن أسس التعليم في كثير من البلاد

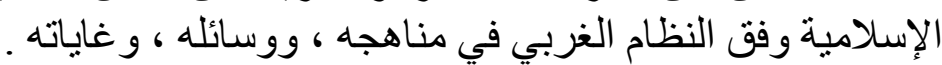

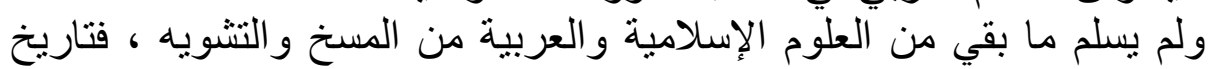

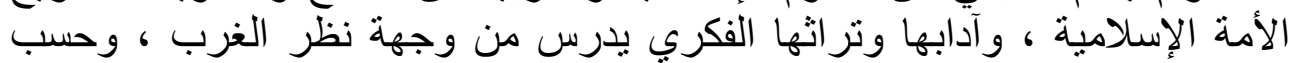

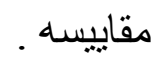

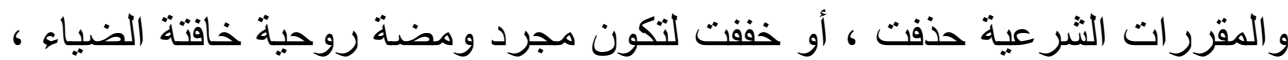

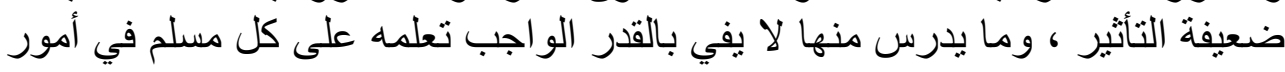

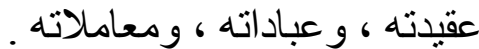

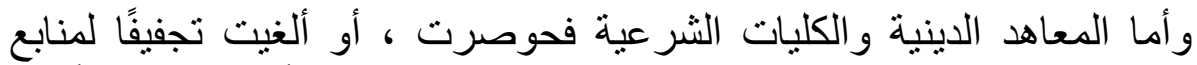
التدين وموارده ـ ولما كان التدين فطرة إنسانية مشتركة بين الأمم ، ثم هو أيضًا 


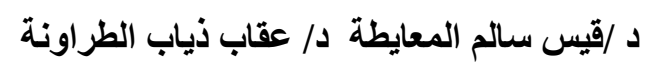

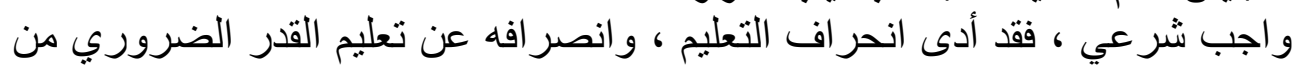

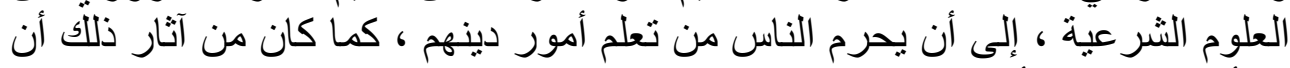

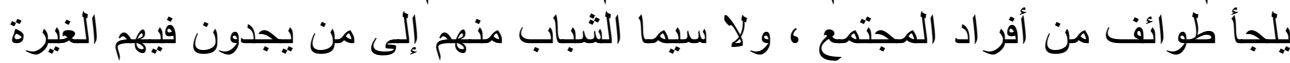

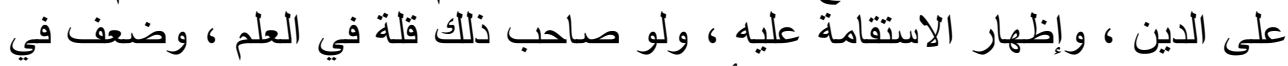

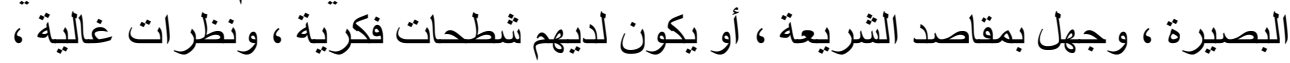

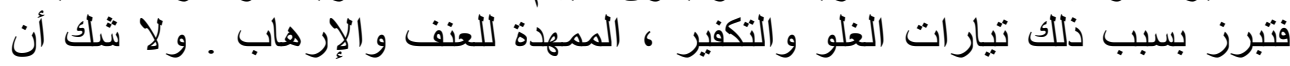

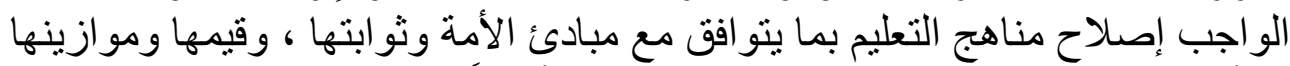

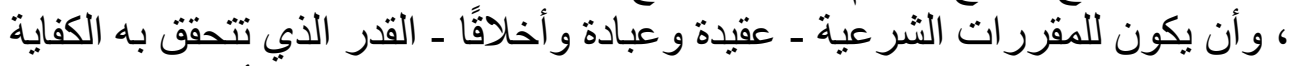

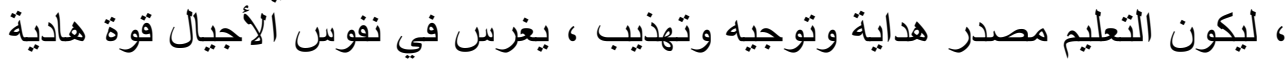

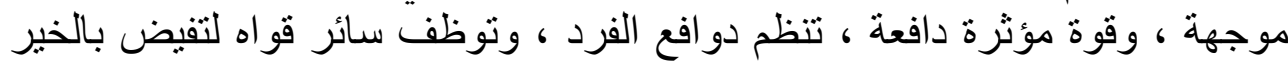

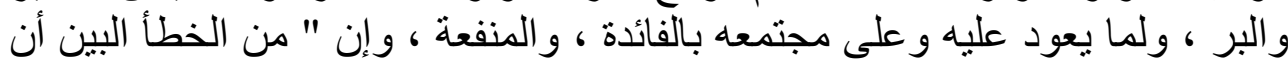

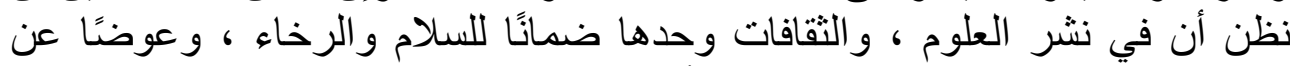

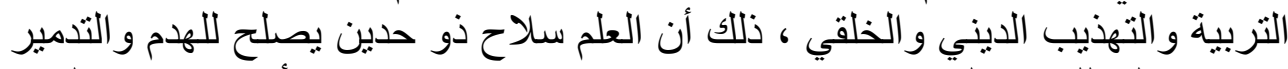

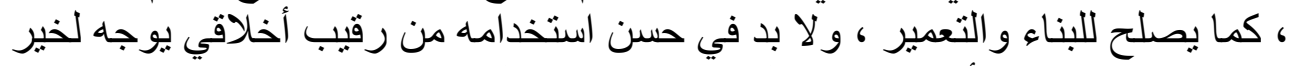

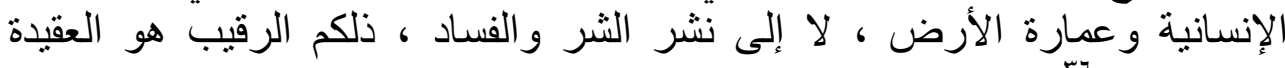
و الإيمان " . الإنيانة و

\section{المبحث الثالث \\ دور كليات الثريعة في الجامعات الأردنية في تكوين وتتمية شخصية الطالب المعتدلة .}

المطلب الأول : أهمية المناهج الجامعية في كليات الشريعة في مكافحة التطرف .

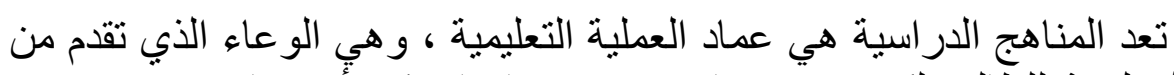

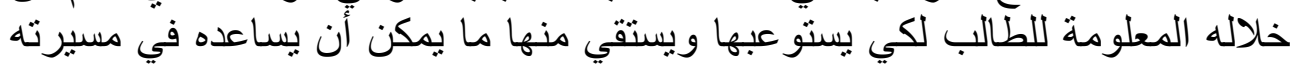

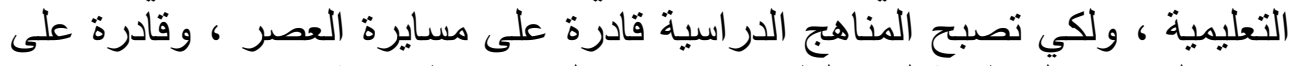

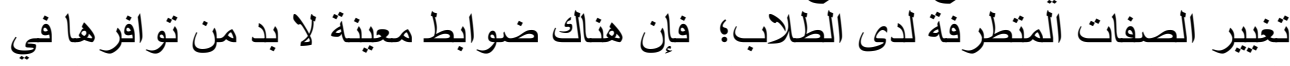

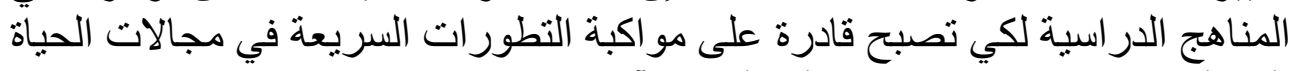

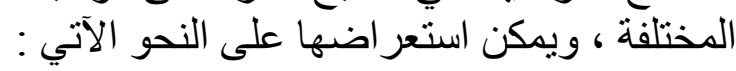

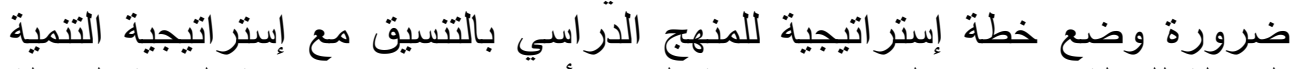

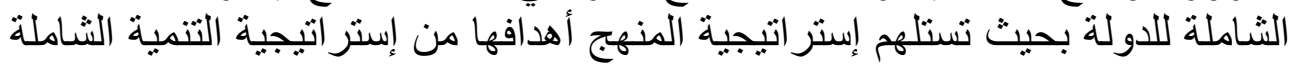
للاولة . ويقصد بذلك أن تكون الأهداف التربوية منبثقة من حاجات المجتمع المتغيرة،

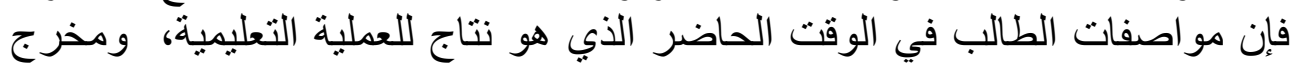


دور المؤسسات الدينية في تجديد الخطاب الديني

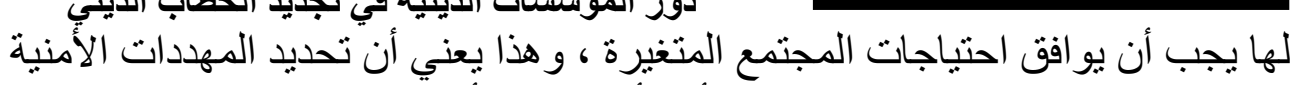

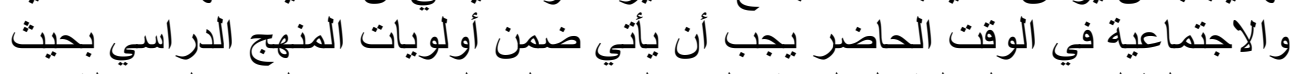

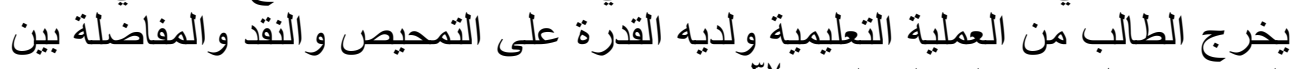

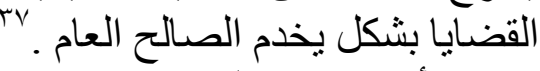
يجب أن يكون هنالك تتاسق بين مفردات المنهج و عدد الساعات المقات المررة على الطى الطالب

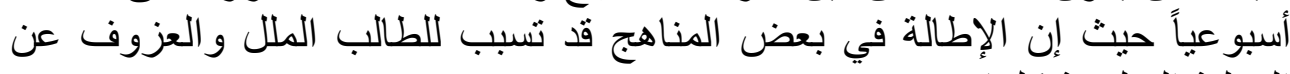

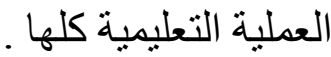

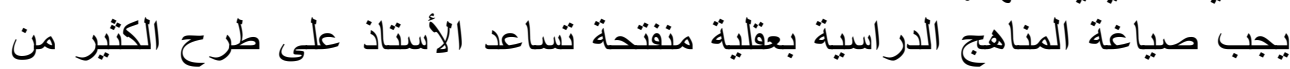

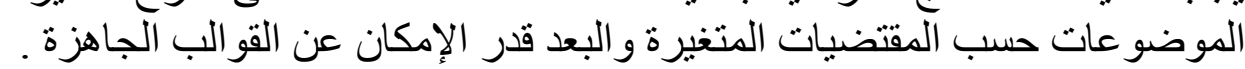

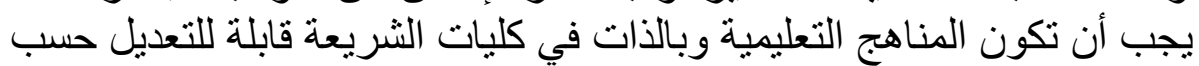

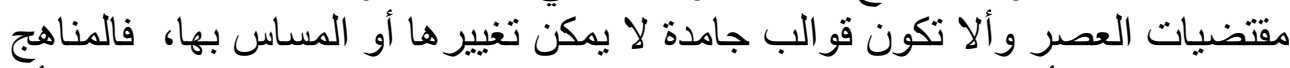

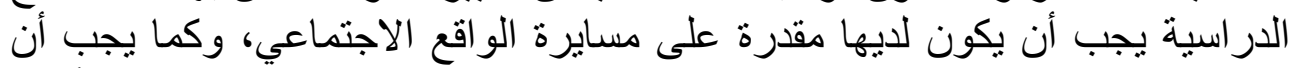

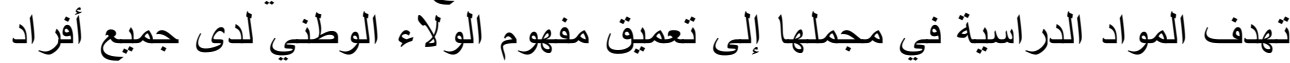

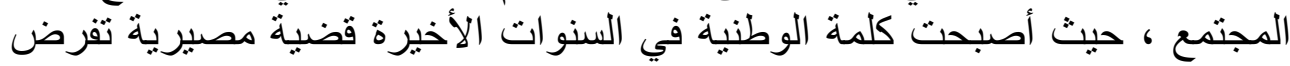

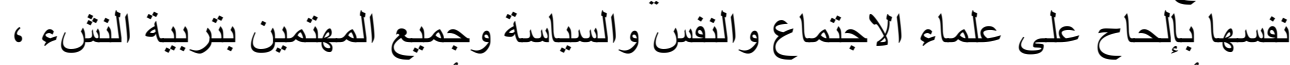

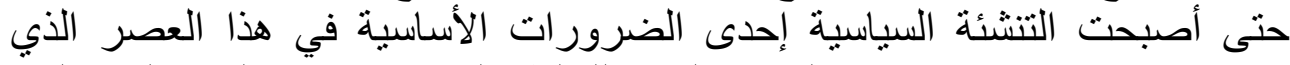

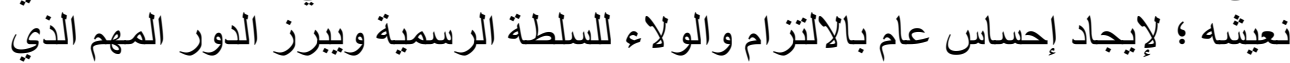

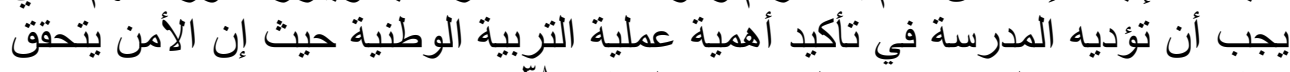

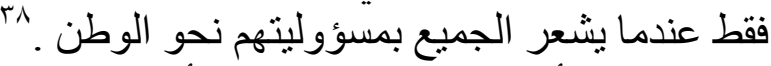

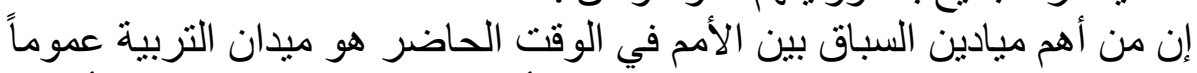

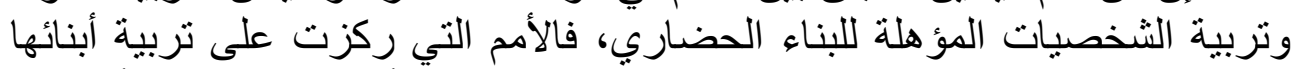

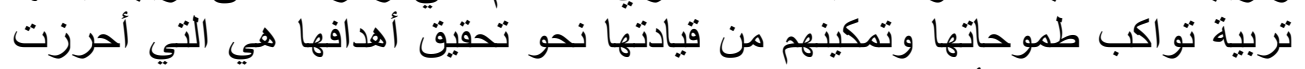

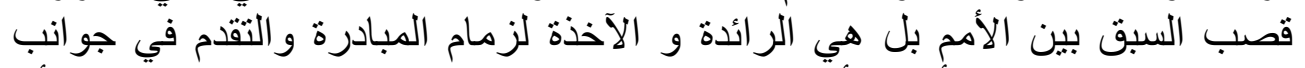

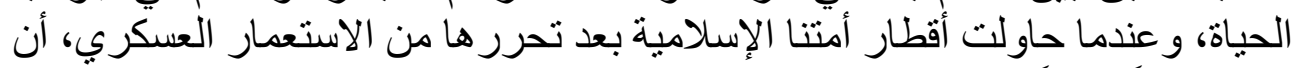

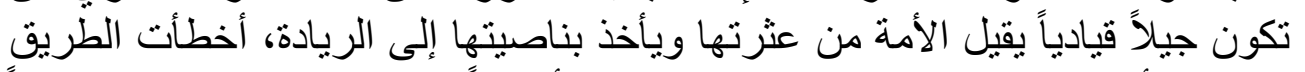

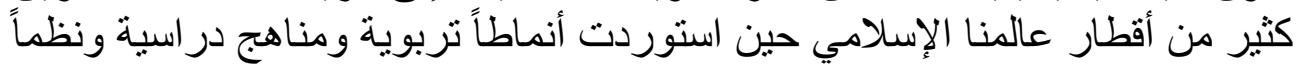

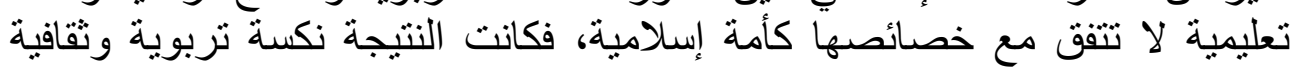

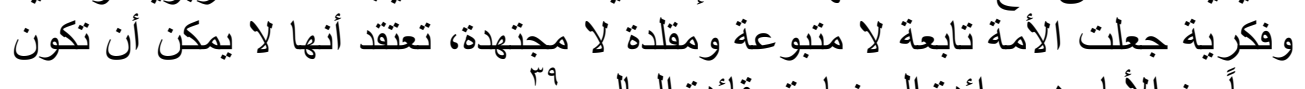

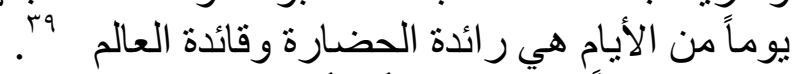

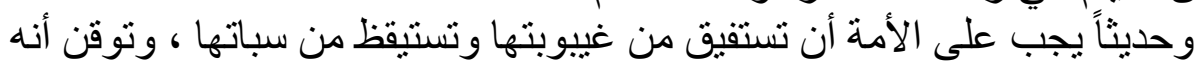

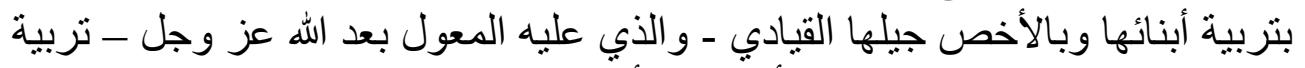

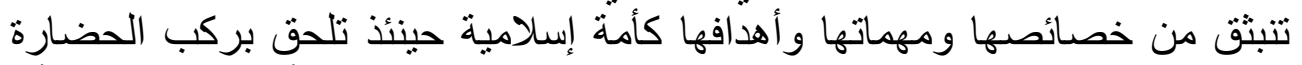

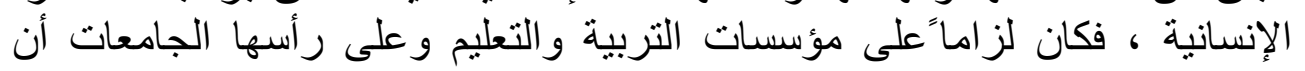


د /قيس سالم المعايطة د/ عقاب ذياب الطراونة

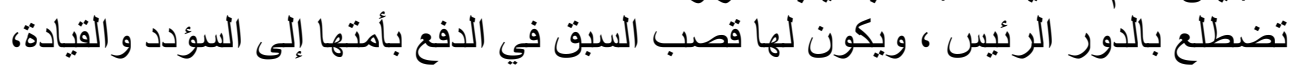

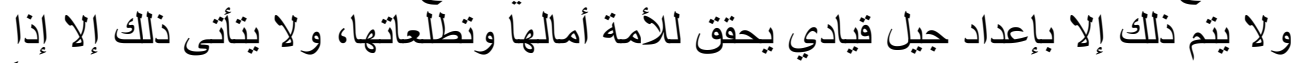

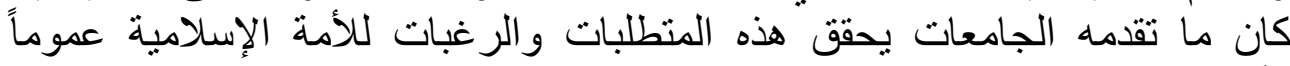
المطلب الثاني : دور المناهج الجامعية التي تدرس في كليات الثريعة في تثمية

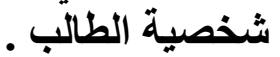

دور المناهج الجامعية في تنمية شخصية الطالب المتزنة المعتدلة والبعيدة

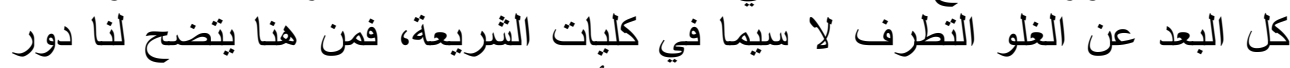

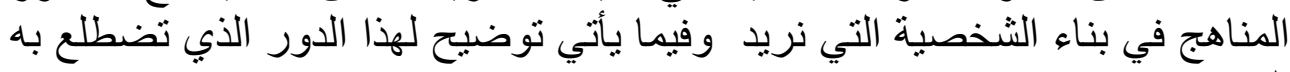

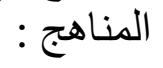

1 ـ تعتبر المناهج الدراسية أحد أركان مسيرة التربية والتعليم الرئيسة المسئولة عن

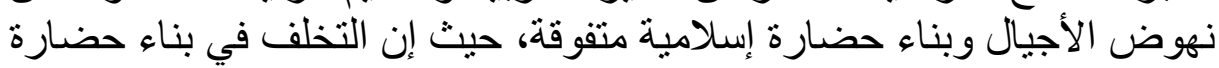

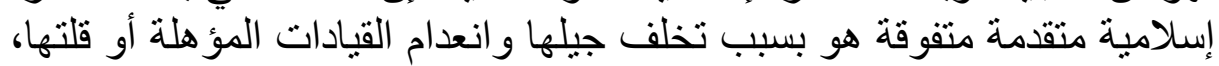
وسبب هذا التخلف هو تخلف الأجيال المعدة في المؤسسات التعليمية و التربوية

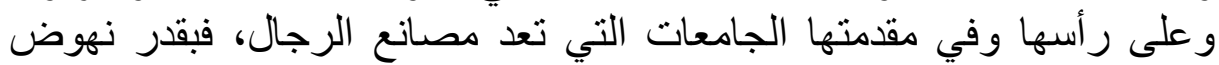

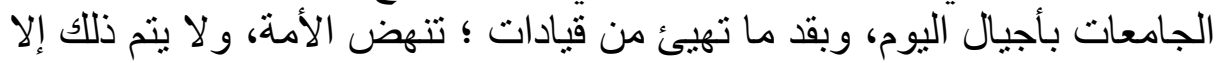

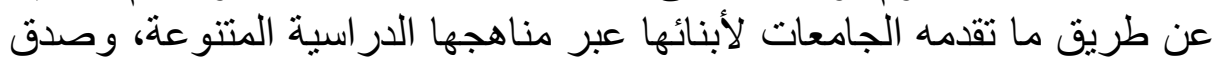

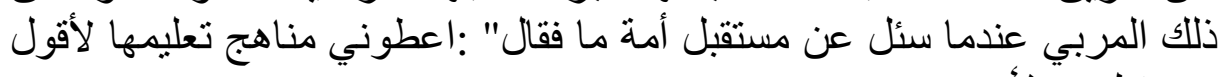

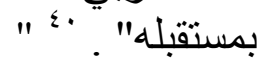
r- تعد المناهج الدر اسية عموماً والجامعية خصوصاً وسيلة هامة من وسائل التربية،

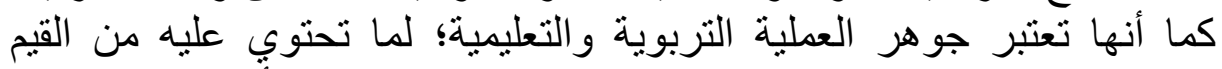

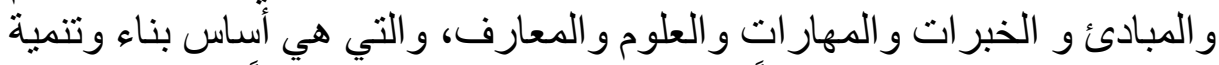

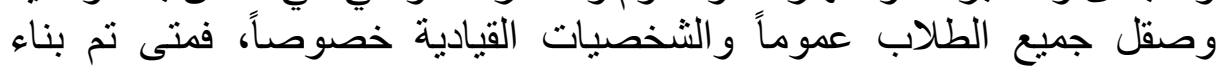

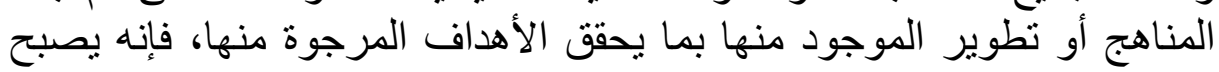

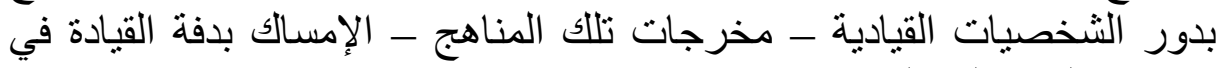
مجالات الحياة المختلفة

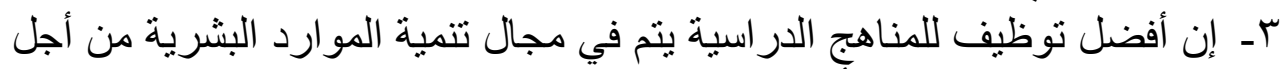

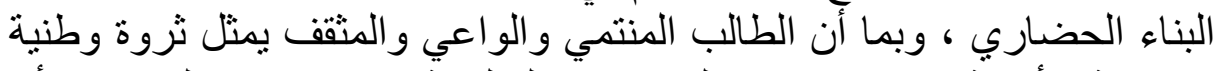

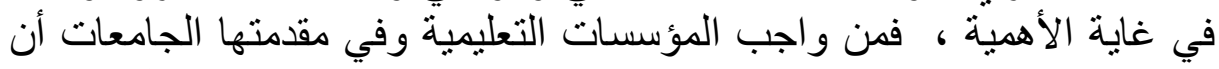

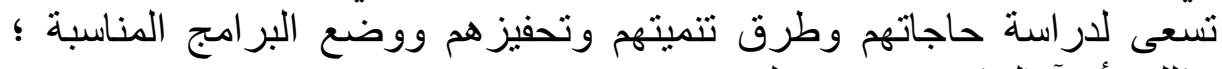
وذلك لأن آمال كبرى تنعقد عليهم. 
دور المؤسسات الدينية في تجديد الخطاب الايني

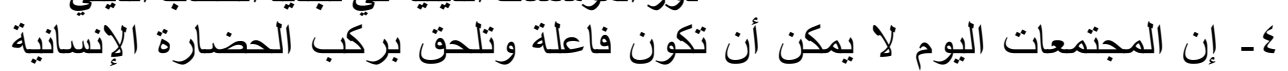

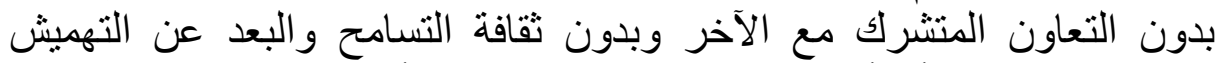

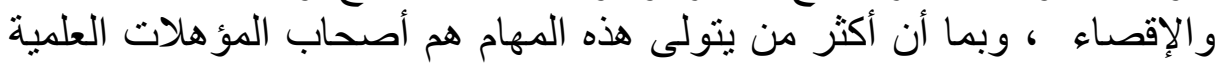

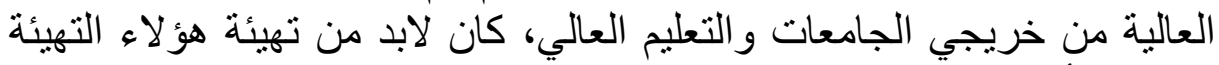

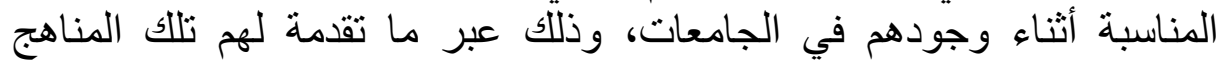

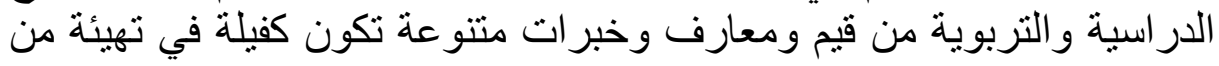
تتطلع إليهم المجتمعات اليوم.

هـ تتمية الثخصيات القيادية القادرة على الإسهام في عمارة الأرض وقيادة الأمة

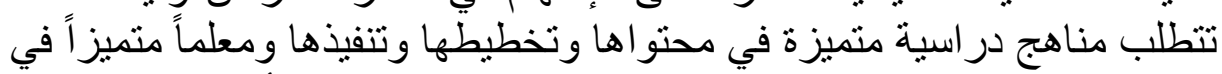

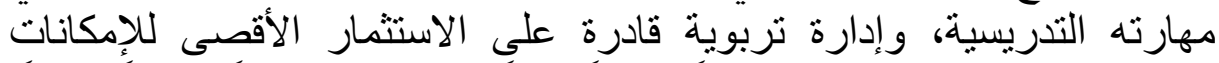

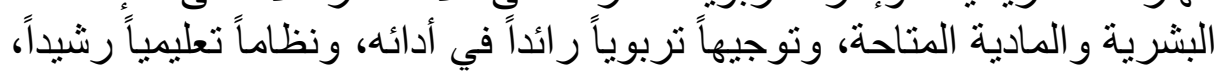

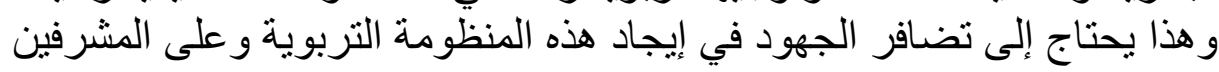

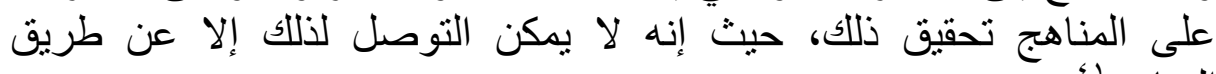
المناهج " المناهج

\section{الخاتمة : وفيها ابرز النتائج والتوصيات.} إيتضح لنا من خلال ما قدمنا من دراسة جملة من النتائج المهمة في هذا البحث من

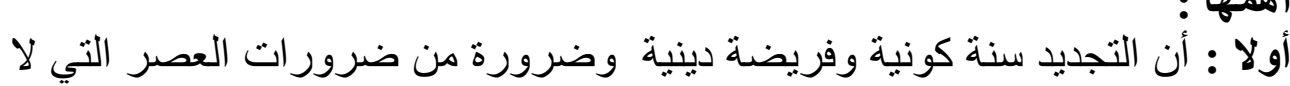

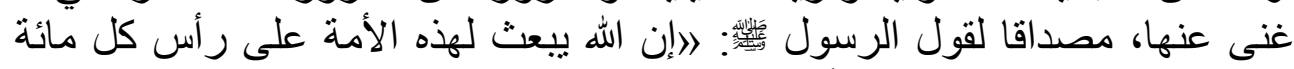

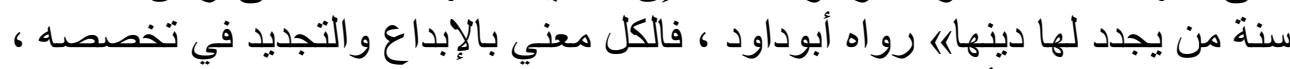
و الخطاب الديني لله أهله وهم السادة العلماء و الفقهاء.

ثثانياً : هناك ثمة فرق بين التجديد في الخطاب الديني والخطاب الثرع، فما يميز

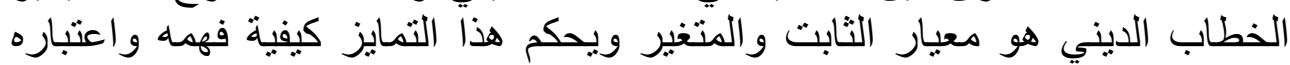

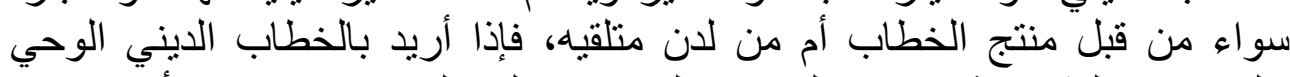

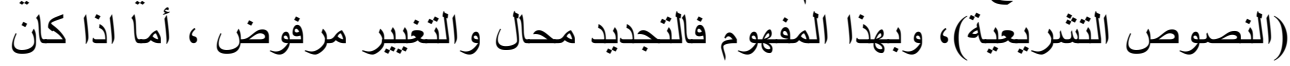

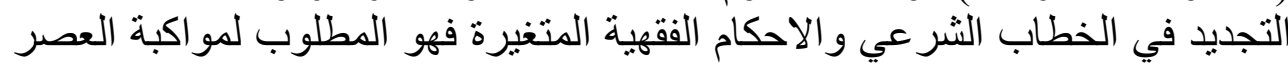

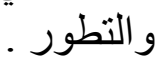
ثالثاً : تجديد الخطاب الديني هو مسؤولية المجتمع كله بكل فئاته و الجهات المؤسسة له له ولهي

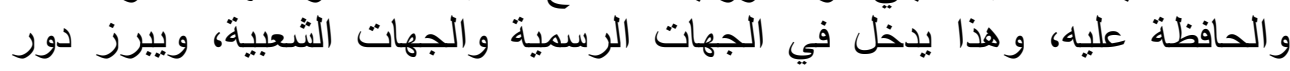




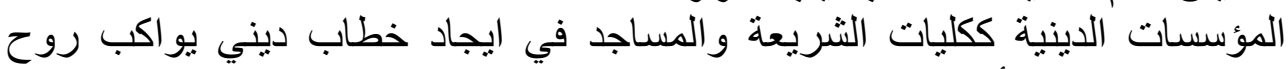

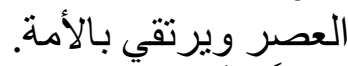

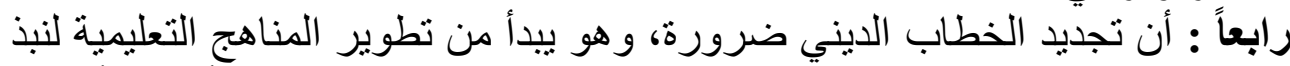

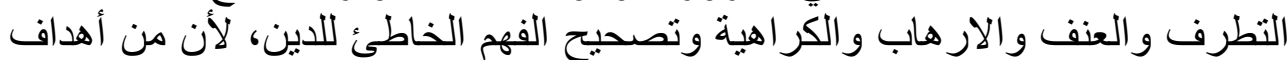

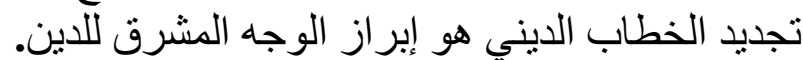

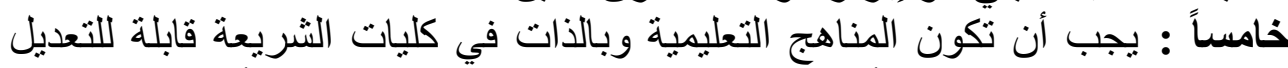

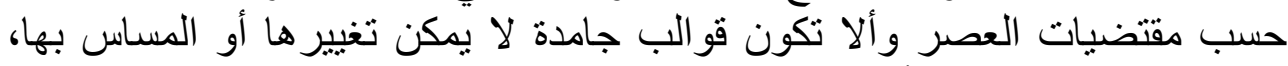

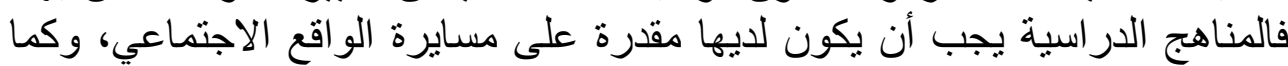

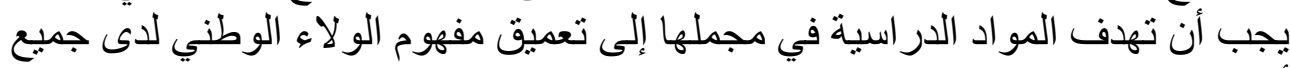

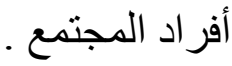

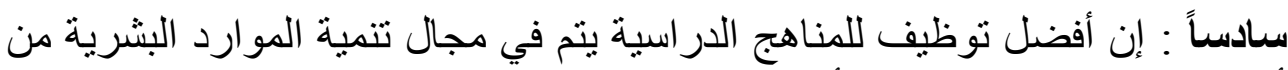

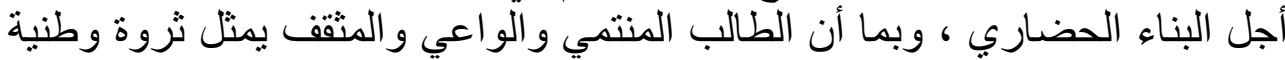

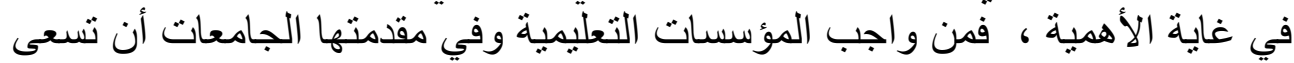

لار اسة حاجاتهم وطرق تنميتهم وتحفيز هم ووضع البع البر امج المناسبة.

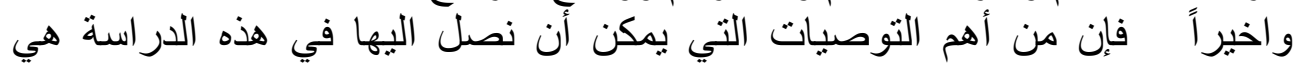

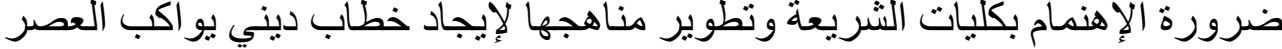

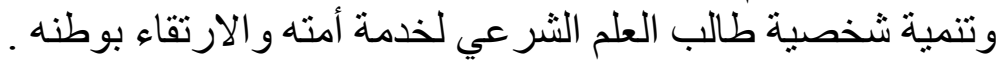

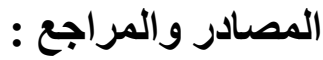

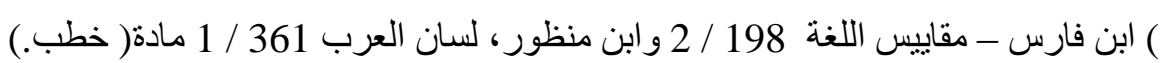

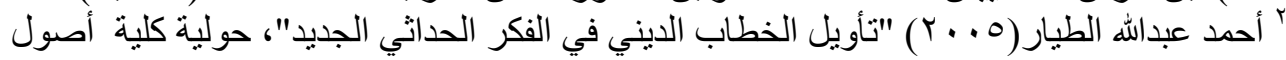

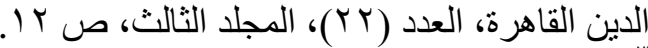
r سيف الدين الآمدي (910 (1) ) " الإحكام في أصول الصول الأحكام "، الطبعة الأولى، دار الكتب العلمية،

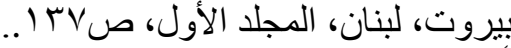

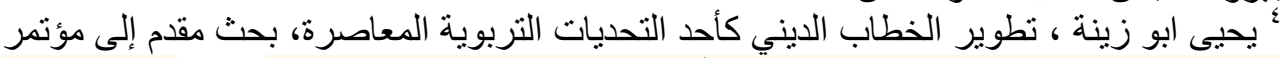

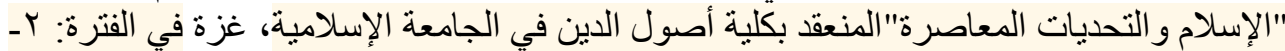
T

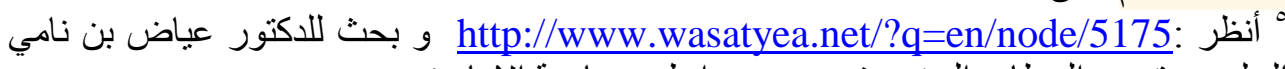

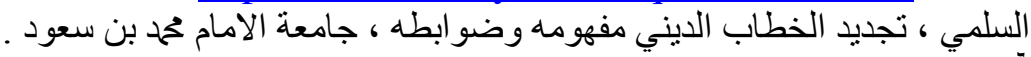

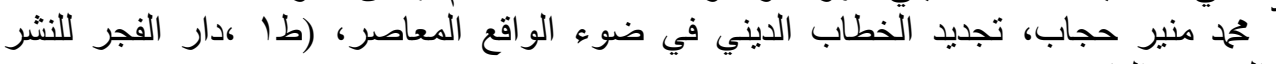

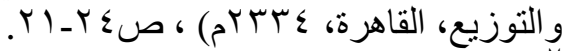

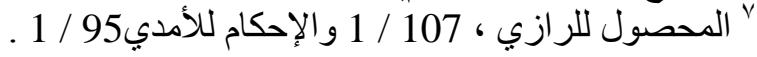

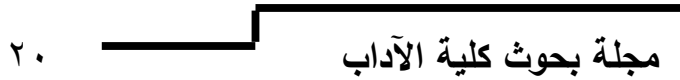


دور المؤسسات الدينية في تجديد الخطاب الديني

^ علي بن عبد العزيز بن علي الثبل، الجذور التاريخية لحقيقة الغلو و التطرف والإر هاب والعنف،

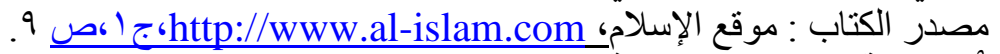

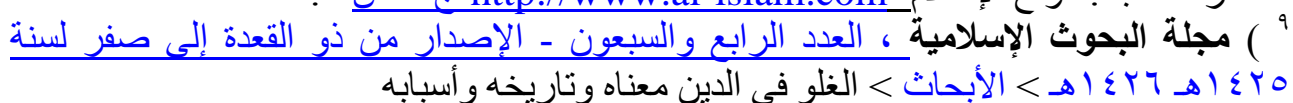

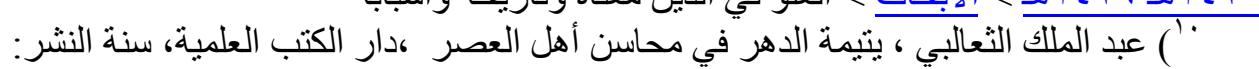

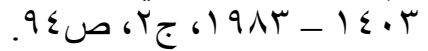

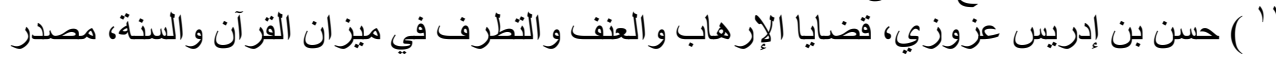

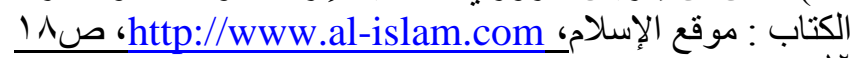

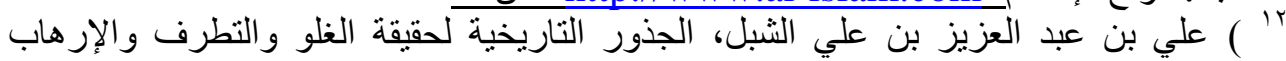

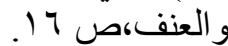

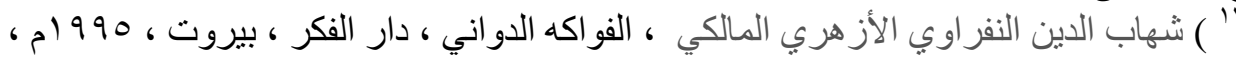

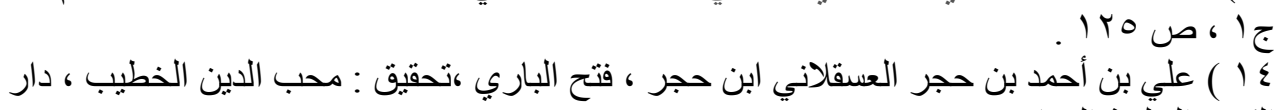

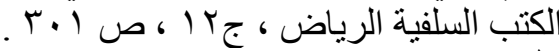

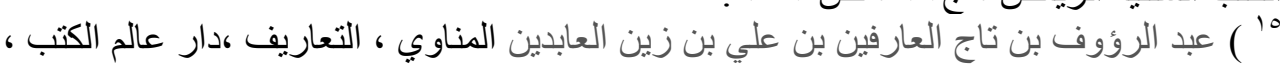

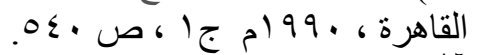

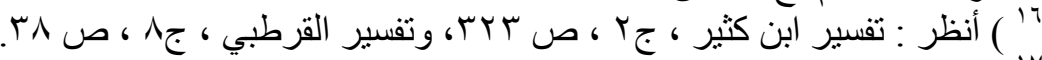

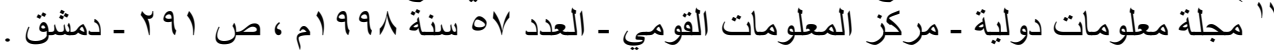

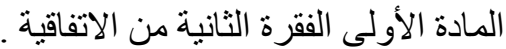

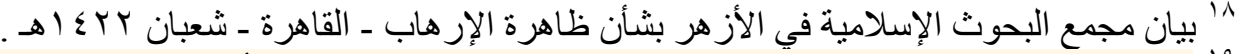

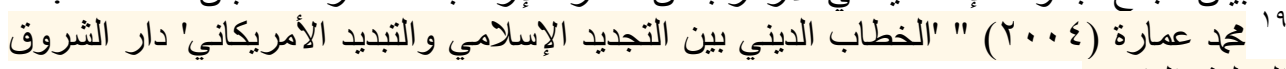

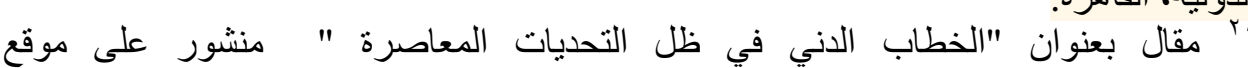
http://www.wasatyea.net r عبدالسلام حمود الأنسي ، مفهوم الخطاب الديني ومعوقاته ، مقال منشور على موقع https://www.assakina.com

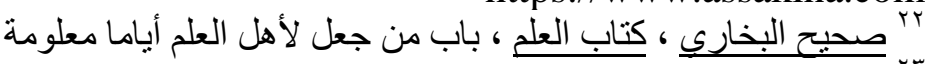

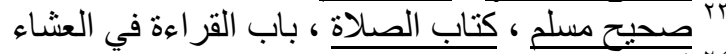

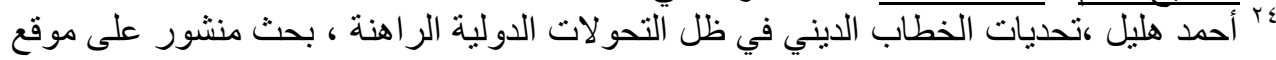
https://repository.nauss.edu.sa

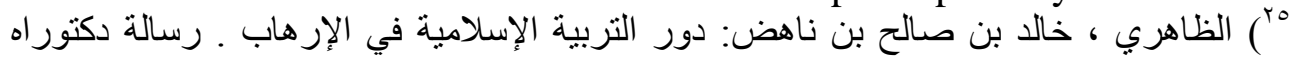

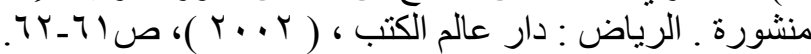

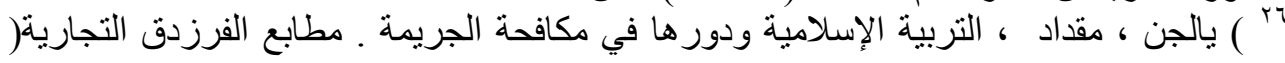

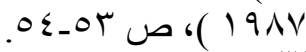

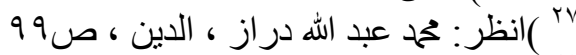

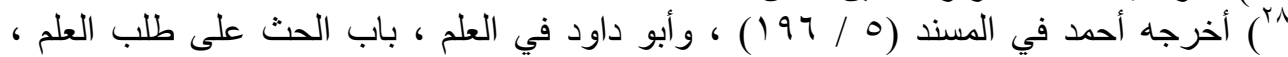

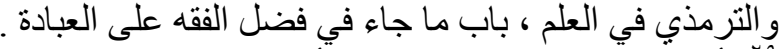

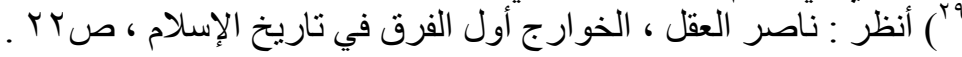


د /قيس سالم المعايطة د/ عقاب ذياب الطراونة

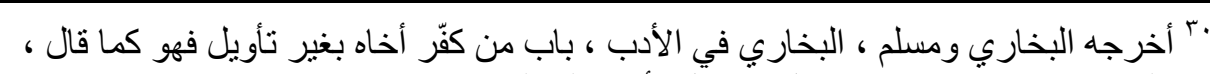

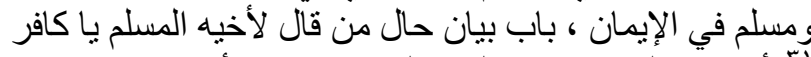

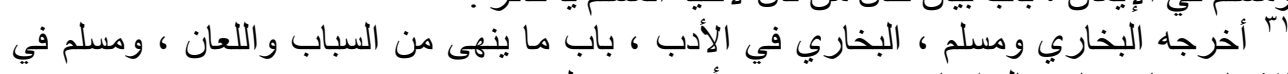

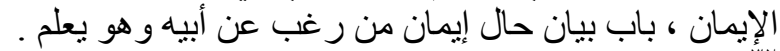

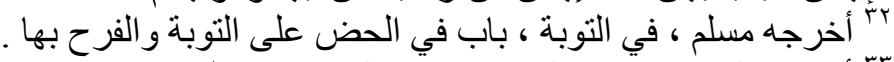

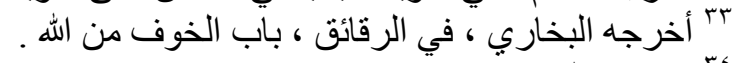

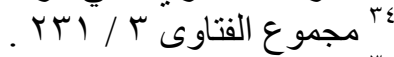

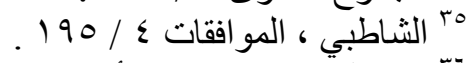

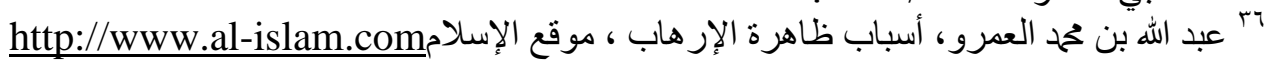

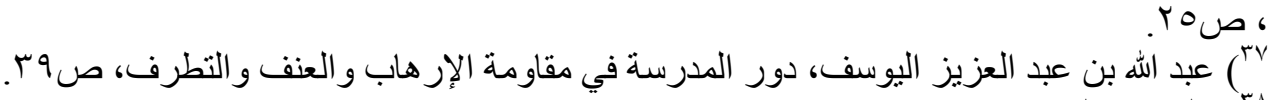

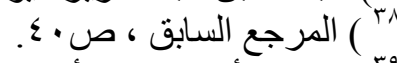

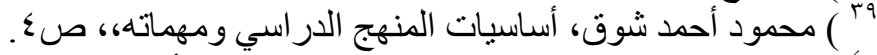

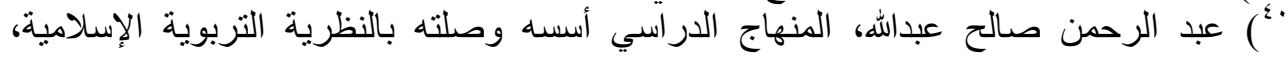

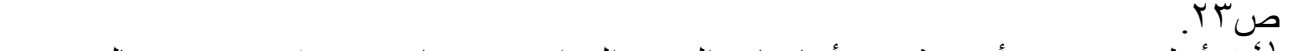

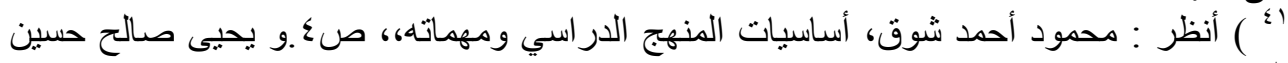

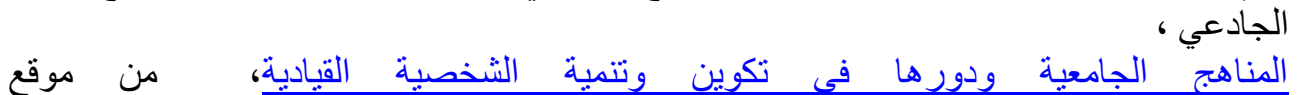
.http://www.alukah.ne

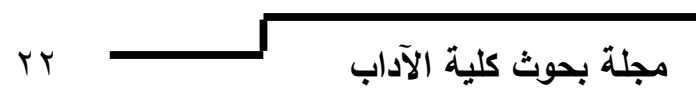

